\title{
SOURCES OF \\ POTENTIAL BIOLOGICAL DAMAGE FROM ONCE-THROUGH COOLING SYSTEMS OF NUCLEAR POWER PLANTS
}
C. P. Goodyear
C. C. Coutant
J. R. Trabalka 


\section{DISCLAIMER}

This report was prepared as an account of work sponsored by an agency of the United States Government. Neither the United States Government nor any agency Thereof, nor any of their employees, makes any warranty, express or implied, or assumes any legal liability or responsibility for the accuracy, completeness, or usefulness of any information, apparatus, product, or process disclosed, or represents that its use would not infringe privately owned rights. Reference herein to any specific commercial product, process, or service by trade name, trademark, manufacturer, or otherwise does not necessarily constitute or imply its endorsement, recommendation, or favoring by the United States Government or any agency thereof. The views and opinions of authors expressed herein do not necessarily state or reflect those of the United States Government or any agency thereof. 


\section{DISCLAIMER}

Portions of this document may be illegible in electronic image products. Images are produced from the best available original document. 
This report was prepared as an account of work sponsored by the United States Government. Neither the United States nor the United States Atomic Energy Commission, nor any of their employees, nor any of their contractors, subcontractors, or their employees, makes any warranty, express or implied, or assumes any legal liability or responsibility for the accuracy, completeness or usefulness of any information, apparatus, product or process disclosed, or represents that its use would not infringe privately owned rights. 
Contract No. W-7405-eng-26

ENVIRONMENTAL SCIENCES DIVISION

SOURCES OF POTENTIAL BIOLOGICAL DAMAGE

FROM ONCE-THROUGH COOLING SYSTEMS OF

NUCLEAR POWER PLANTS

C. P. Goodyear

C. C. Coutant

J. R. Trabalka

JULY 1974

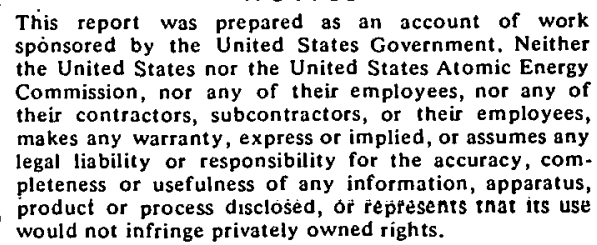

OAK RIDGE NATIONAL LABORATORY

Mak Ridge, Tennesace 37830

operated by

UNION CARBIDE CORPORATION

for the

U.S. ATOMIC ENERGY COMMISSION 


\section{THIS PAGE \\ WAS INTENTIONALLY \\ LEFT BLANK}


CONTENTS

Page

FOREWORD . . . . . . . . . . . . . . . . . . v v

INTRODUCTION . . . . . . . . . . . . . . . . . . 1

1. THERMAL EFFECTS . . . . . . . . . . . . . 2

1.1 Decomposers . . . . . . . . . . . . . . . 3

1.2 Producers . . . . . . . . . . . . . 4

1.3 Consumers . . . . . . . . . . . . . 6

2. MECHANICAL AND PRESSURE CHANGES . . . . . . . . . 14

3. IMPINGEMENT . . . . . . . . . . . . . . . . 14

4. ENTRAINMENT . . . . . . . . . . . . . . . 15

4.1 Decomposers . . . . . . . . . . . . 16

4.2 Producers . . . . . . . . . . . . . 16

4.3 Consumers . . . . . . . . . . . . . . 17

5. CHEMICALS . . . . . . . . . . . . . . . 21

5.1 Chlorine . . . . . . . . . . . . . 21

5.2 Copper ................... 25

6. DISSOLVED OXYGEN . . . . . . . . . . . . . . 25

7. INDUCED CIRCULATION . . . . . . . . . . . . 26

8. RADIATION EFFECTS . . . . . . . . . . . . 27

9. COMBINED EFFECTS . . . . . . . . . . . . . . 28

9.1 Direct Effects . . . . . . . . . . . . . 28

9.2 Indirect Effects . . . . . . . . . . 29

10. SUMMARY . . . . . . . . . . . . . . . 31

REFERENCES . . . . . . . . . . . . . . . 32 


\section{THIS PAGE \\ WAS INTENTIONALLY \\ LEFT BLANK}


This report presents a general introduction to pertinent biological and ecological information related to predicting the environmental effects of operating a nuclear power plant equipped with once-through, open circuit cooling of steam turbine condensers. Information of this nature forms the basis (along with detailed, site-specific data) for assessments of ecological impacts of nuclear power plants by the ORNL Environmental Sources Division staff who assist as members of the Environmental Statements Project at ORNL. 


\section{SOURCES OF POTENTIAL BIOLOGICAL DAMAGE FROM \\ ONCE-THROUGH COOLING SYSTEMS-}

OF NUCLEAR POWER PLANTS

\section{INTRODUCTION}

There are seven principal sources of potential direct biological damage from operation of a once-through cooling system and an eighth, their combined effects (Fig. 1). These-are:

1. Temperature increases from the warm cooling water, which may cause both direct and indirect effects (metabolism, growth, disease, predation, etc.).

2. Mechonical and pressure changes, which may damage small organisms that pass through pumps and condenser tubing.

3. Impingement on intake screens of large organisms, principally fish, drawn into the cooling-water intake.

Entrainment refers to the combined effects of. impingement, temperature increases, and mechanical (and pressure) changes on small organisms. (plankton, small fish) that pass through the cooling system. The magnitude of the entrainment prob- . lem is determined principally by the abundance of suspended small organisms and the percentage of the water body (or flow) that is pumped through the plant.

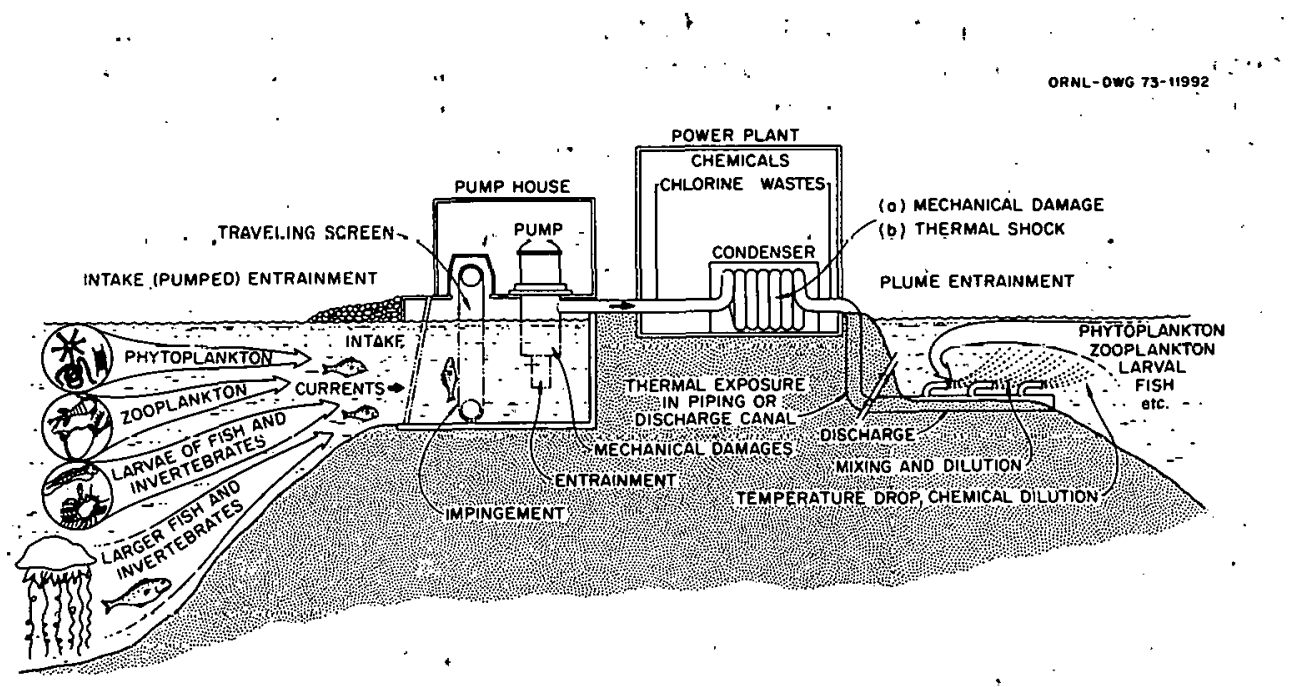

Fig. 1. Schematic view of some sources of potential biological damages for power plants with once-through cooling. 
4. Chemicals used as biocides (usually chlorine) to remove slimes from the condenser tubing and perhaps other chemicals released to the cooling water from a variety of plant operations; all of the chemicals may be toxic to aquatic life.

5. Decreases in the concentration of dissolved oxygen in water passed through the power plant or, more likely, in the water body as a result of increased biochemical oxygen demand at warmer water temperatures.

6. Induced circulation of a water body, both in the local area of the discharge (which may influence migrations) and in the wider range of the water body (which may change normal seasonal patterns).

7. Radiation, derived largely from radionuclides taken up by aquatic organisms, which may induce radiation damage if concentrations of the nuclides are sufficiently high.

8. Combinations of the above effects, which may cause effects greater than the sum of individual effects (synergism).

Construction activities add additional sources of biological damage. Destruction of wildlife habitat and silting of nearby water bodies during construction may result from such activities.

\section{THERMAL EFFECTS}

Temperature is a particularly important factor that governs the occurrence and behavior of organisms. It may not only affect the distribution of a single species but also modify the species composition of a community or an ecosystem.

Organisms are known to have upper and lower thermal tolerance limits, optimum growth temperatures, preferred temperatures in gradients, and restricted temperature limits for migration, spawnIng, and development. Temperature governs the occurrence, behavior, and metabolism of aquatic organisms, and can modify the species composition of a community or ecosystem. Temperature also affects various physical parameters, including viscosity, sperific gravity, and solubility of gases, thus indirectly affecting biological processes.

Aquatic organisms respond to water temperature, not to quantity of heat. $\Lambda$ lucid prcscntation of this fundamental aspect of aquatic physiology is given by 0 . Kinne ${ }^{l}$ in his introduction to the temperature section of a treatise on marine ecology. Organisms cannot sense the quantity of heat but only differences in, 
or levels of, heat intensity, i.e. temperature. Thus, water quality assessments should be based on temperature rather than amounts of heat additions.

Among periodic reviews of temperature effects on organisms and on aquatic communities, several are outstanding. ${ }^{1-6}$ Some of the effects have been analyzed in the context. of thermal modification by power plants. ${ }^{7-14}$ Bibliographic information is available from Kennedy and Mihursky, 15 from Raney, Menzel, and Weller, 16 and from annual literature reviews published by the Water Pollution Control Federation. 17-23

Generally, tropical and subtropical species are more stenothermal (tolerant to only a narrow range of temperatures) than those of higher latitudes, and marine forms are more stenothermal than are freshwater or estuarine forms. 24 In this connection, Naylor 25 notes that estuarine species are more tolerant of heated effluents than are marine forms and concludes that some cold-water stenothermal species may'be eliminated by heated discharges, whereas eurythermal (tolerant to a wide range of temperatures). species may be increased.

\subsection{Decomposers}

The temperature of most natural waters, even in summer, is below the optimum for most bacteria. Increasing the water temperature increases the bacterial multiplication rate when the environment is favorable and the food supply is abundant. Increasing the water temperature within the growth range of the bacteria causes a more rapid die-off when the food supply is limited. ${ }^{26}$. Consequently the few-degree increase in temperature due to the discharge of heat by a power plant would be expected to favor increased bacterial growth during most of. the year only. if the standing crop of bacteria is less than the carrying capacity of their food supply. Because of metabolic considerations, temperature increases that favor population growth may be counteracted by a reduction in the carrying capacity of the area. However, if; in addition to the increased temperature, an associated increase occurs in avallable organic material (e.g., fish or other organisms killed by plant operation), standing crops of bacteria might increase. Bacterial counts in the influent and effluent waters of a power plant on the Patuxent River estuary remained constant when a rapid temperature change (but no chlorination) occurred. 27 


\subsection{Producers}

Inherent in the question of availability of different algal groups as food for invertebrates is the succession of the algae with increasing temperature. As Patrick ${ }^{28}$ notes in her review of the effects of temperature on freshwater algae, each species in nature has its own range of temperature tolerance and its ranges of optimum growth, photosynthesis, and reproduction. In general, the diatoms have the largest number of species; their tolerance to temperatures less than $86^{\circ} \mathrm{F}$ is relatively low. The tolerances of the green algae cover a wide temperature span. The blue-green algae have more species that are tolerant of very high temperatures. However, some species in all groups tolerate an unusual extreme for their group. Under normal seasonal conditions, a succession of opccica criot on the came cubotrate. The euccession is largely the result of changes in water temperature and in light intensity through the optimums for the various species. As the temperature increases or decreases, one species replaces another as the dominant organism. Nature imposes many other pressures on a species, including interspecies competition and predation; thus, the temperature range of maximum development in a stream may not be exactly the same as that in the 1aboratory. Figure 2 indicates the most commonly observed type of population shift. Since this figure was introduced by Cairns, 29 it has been used repeatedly and is widely accepted, although, as Coutant ${ }^{13}$ points out, it is a generalized pattern, which is not always tollowed by algal populations in the field.

Reports of field studies of the biota associated with discharge canals of power plants, where the water temperature is still essentially as high as it was when the water left the condensers, note dominance of the periphyton community by heat-tolerant blue-green algae when water temperatures exceed about $86^{\circ} \mathrm{F}$. Reports by Trembley 30 indicate that the periphyton grown on glass slides was dominated to a high degree by blue-green algae when the temperature exceeded $94.1^{\circ} \mathrm{F}$ in the discharge canal of the Martin's Creek Power Plant on the Delaware River. Fewer species were on the slides than when the water was cooler, but those that remained were represented by a larger number of individuals. This condition is generally recognized as an indication of an abnormal community structure. The blue-green algae appeared to be used as food by fewer organisms than were other algal classes. However, the alteration of community structure that was due to chlorination of the cooling water is difficult to determine.13 


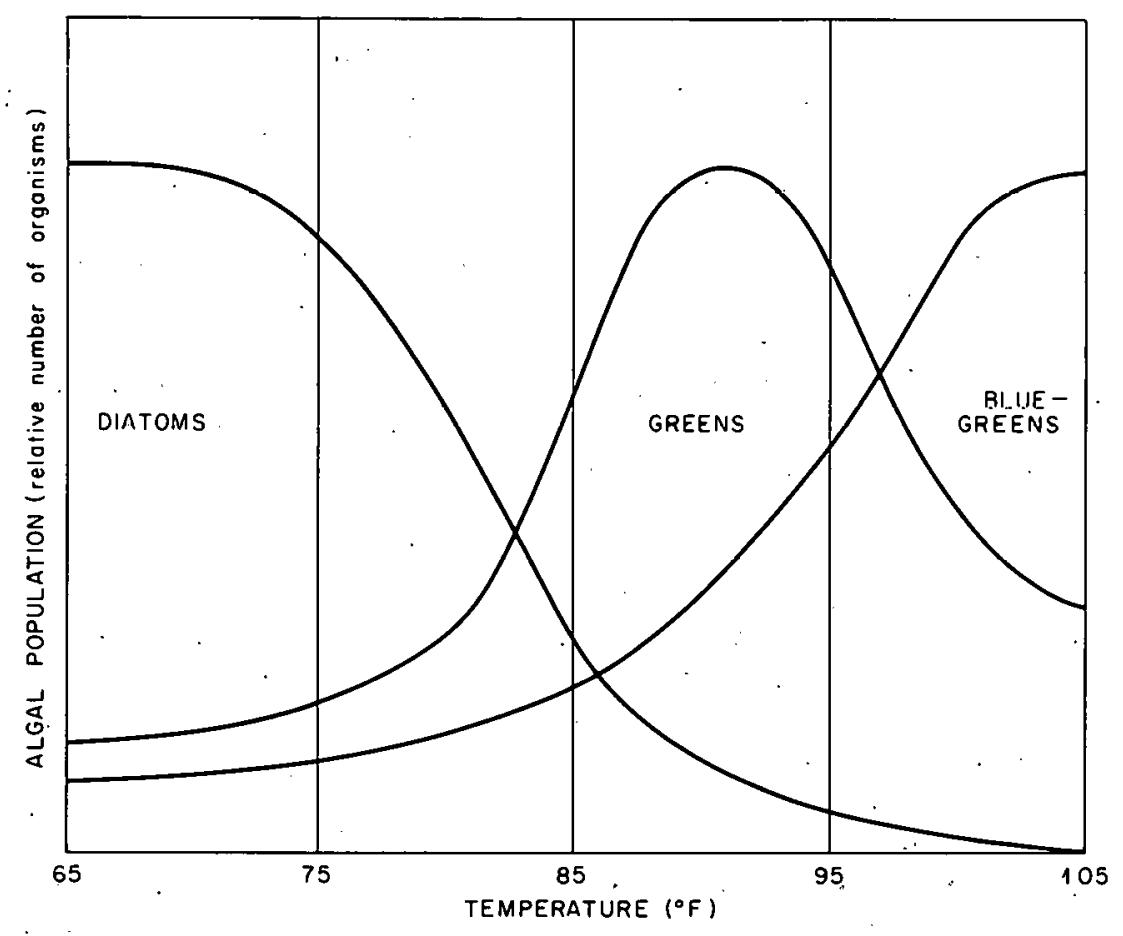

Fig. 2. Population changes in algal groups with changes in temperature.

Foerster ${ }^{31}$ discusses the apparent early arrival of spring seasonal successions in periphyton of the discharge canal of the Yankee Atomic Power Plant on the Connecticut River. Buck ${ }^{32}$ reports a noticeable shift from diatoms to blue-green algae in plankton in the area of thermal effluent. Presumably, these planktonic forms were derived from the periphyton populations of the mile-long canal, although a detailed report of this study has not yet been published. Similar changes in the species composition of plankton in cooling water are reported by Beer and Pipes, ${ }^{33}$ who describe a shift from diatom dominance in the inlet to dominance by unicellular green algae in the effluent canal of the Dresden Station on the Illinois River.

In a September survey, Oscillatoria (a blue-green filamentous alga) covered all bottom materials in shallow water of the discharge canal and the river bed close to the confluence of the discharge from the John Sevier. Steam Plant (Tennessee Valley Authority) with 
the Holston River, Tennessee. ${ }^{13}$ However, no large-scale replacement of cold-water marine algae by warm-water-tolerant forms was found by North ${ }^{34}$ at the Morro Bay discharge canal; the entire algal flora was simply depleted at the warmer temperature.

The lethal temperature for the algae varies with the species. 28 Most of the algal species studied to date have a lethal temperature in the range $91.5^{\circ}$ to $113^{\circ} \mathrm{F}$; for the majority, the lethal temperature is near $111^{\circ} \mathrm{F}$. Diatoms that require cooler temperature (stenotherms) are generally most sensitive to temperature change and can withstand an $18 \mathrm{~F}^{\circ}$ temperature change. Diatoms suited to warmer temperatures can tolerate temperature changes ${ }^{6}$ from $27^{\circ}$ to $36 \mathrm{~F}^{\circ}$.

At the Indian Point plant on the Hudson River, the diatom Melosira io dominant throughout moot of the year, although ito dominance declines during the summer period of high temperatures and salinity. Many other species are also consistently present. ${ }^{35}$ However, a seasonal change in composition occurs which is characterized by diatom dominance much of the year, with green and blue-green algae becoming more abundant in late summer and early fall. ${ }^{36}$ The pattern of dominant algal forms (Fig. 3) conforms to the typical pattern previously described (Fig. 2), although the shifts in abundance of the green and blue-green algae seem to be occurring at lower temperatures than would be predicted.

\subsection{Consumers}

The physiology of aquatic fauna is directly affected by temperature. Changes in temperature may cause increases in metabolism, changes in food-conversion abilities, in reproductive capacity, and in behavior, or even thermal death. Fry and others 37 describe the thermal responses of fish and divide the total range of temperature experience of an organism into several zones. They discern a central zone of thermal tolerance, bounded above and below by zones of an upper and a lower lethal temperature, respectively. The lethal temperature is that which, when a fish is brought rapidly to it from a different temperature, will kill a stated fraction of the population (generally 50\%) within an indefinitely prolonged exposure. In the zones of thermal resistance, an organism can survive for a definite period of time that becomes longer as the acclimation temperature approaches the lethal temperature.

Recent thermal history, referred to as acclimation temperature, profoundly affects the lethal temperature. In general, a history of cold temperatures results in low lethal temperatures, whereas a history of warm temperatures results in elevated lethal temperatures. 


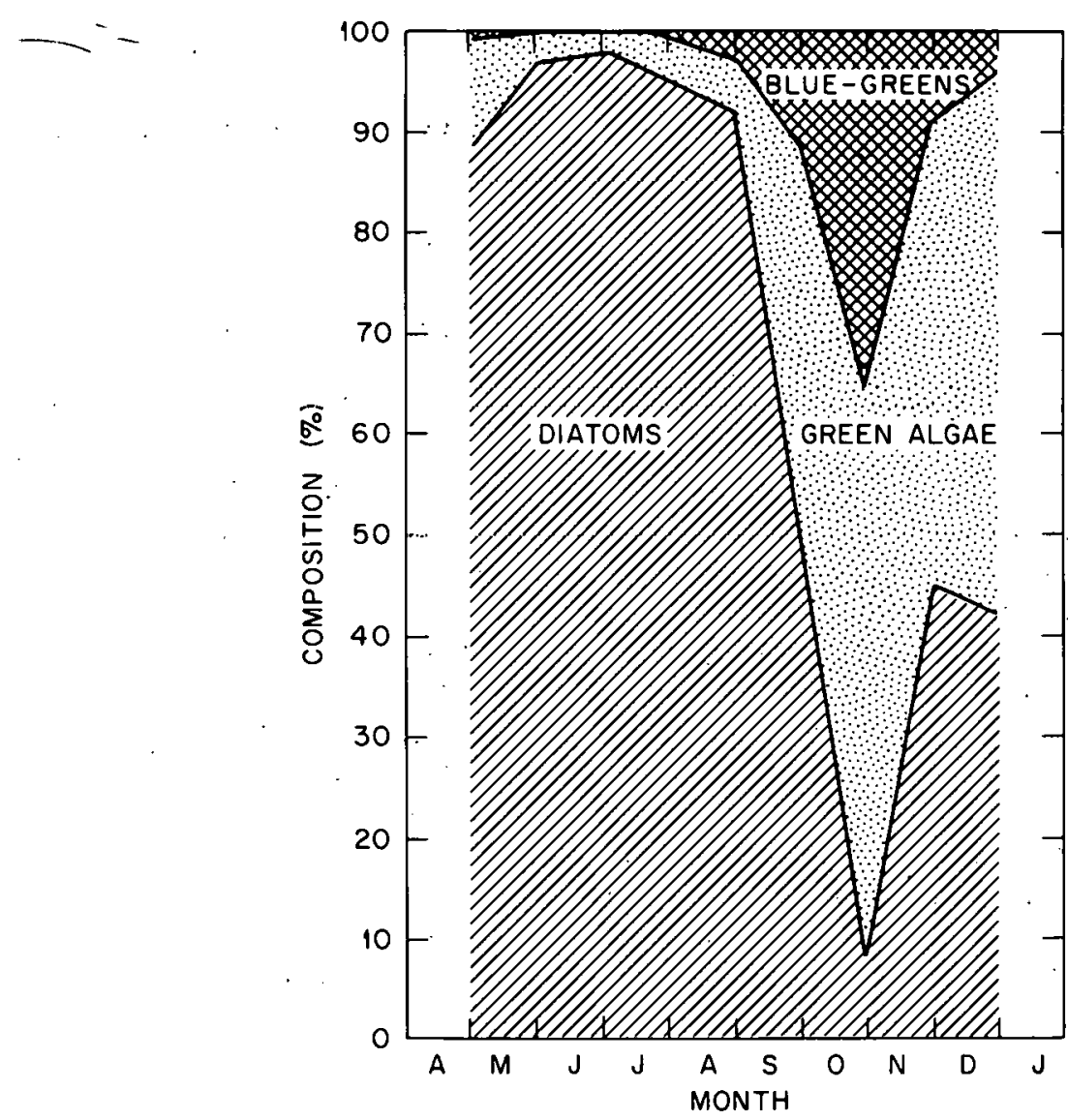

Fig. 3. Relative proportions of diatoms, green algae, and blue-green algae in the standing crop at Indian Point, 1970.

Evidence is accumulating that many cold-blooded (poikilothermic) species can adjust their metabolic activities to a wide range of temperatures. Their adjustment to warmer temperatures is evidenced by increased upper and lower lethal temperatures. The range of adjustment may be considerable, e.g., the goldfish has an upper lethal temperature that varies from about $78.8^{\circ}$ to $104^{\circ} \mathrm{F}$. This hardy species may be one of the extreme cases in this respect. ${ }^{13}$ 
Elevation of lethal temperature is not directly proportional to elevation of acclimation temperature but rather is some fraction of it. The result is that the acclimation temperature and the upper lethal temperature tend to converge upon the ultimate upper lethal temperature, at which both the acclimation and the lethal temperatures are the same. Coutant elaborates on this relationship. 13

The time necessary for thermal acclimation varies among species, as several workers have shown. ${ }^{13}$ Adjustment to higher temperatures is generally fairly rapid. Data of Alabaster and Downing ${ }^{38}$ indicate an elevation of about $1.8 \mathrm{~F}^{\circ}$ per day for the roach; Sprague ${ }^{39}$ found that acclimation temperatures could be raised 4.5 to $9 \mathrm{~F}^{\circ}$ per day for several crustaceans. Once acquired, tolerance to high temperatures may persist for considerable periods after return of a fish to a lower tcmpcraturc.13 Hcat crposuro during acclimation need not be continuous. An intermittent exposure to a different temperature for sufficient hours per day can produce the same acclimation temperature as a continuous exposure. 13 According to several authors, 13 acclimation to low temperature usually tends to shift the lower thermal limits downward, and acclimation to high temperatures tends to shift the lower limits upward. Since intermittent brief exposure to high temperatures can result in markedly increased heat resistance, which is not readily lost during subsequent exposure to low temperatures, possible increased susceptibility to reduced temperatures may result in areas where organisms regularly encounter thermal plumes.

By testing species in the laboratory, Brett 40 noted that a slow rate of decrease in environmental temperature is of greater importance for maintaining life than is a slow rate of increase. Thus, lethal cold can be more important than lethal heat as a factor that affects survival of some species exposed to thermal plumes. Several authors report deaths of fish which resulted from the inability of the fish to rapidly acclimate to decreasing temperatures. 41,42

When fish are exposed to altered temperatures, the duration of the exposure, the size of the fish, and their thermal history are extremely important in determining their survival. Eggs and larvae are very exacting in their temperature requirements, whereas subjuveniles and juveniles appear to be more eurythermal, and adults. tend to be broadly stenothermal. 43

The few data on upper lethal temperatures reported in the literature indicate that larvae of temperate marine fishes have lower upper lethal limits than do the adults.24,43 The experimentally derived median upper temperature for temperate species is $78.8^{\circ} \mathrm{F}$ for larvae and $86^{\circ} \mathrm{F}$ for adults. ${ }^{43}$ Although the upper limits for larvae and adults differ, the absolute ranges of temperatures tolerated are about identical. 43 
The eggs of some species may be especially sensitive to temperature fluctuations. For instance, one of the most important effects noted in Rothschild's ${ }^{44}$ study on eggs of the American smelt (Osmerus mordax) in Maine was the large increase in mortality during daily fluctuations in water temperature of as much as $12.6 \mathrm{~F}^{\circ}$. In contrast, striped-bass eggs (Morone saxatilis) survived in water whose temperature varied about $20 \mathrm{~F}^{\circ}$ daily. ${ }^{45}$

The thermal tolerances of the invertebrate herbivores that are generally most active in grazing algal populations are not known accurately. Coutant 46 observed a reduction in the normal complement of Delaware River invertebrates when the daily maximum temperature was near $89.6^{\circ} \mathrm{F}$. Chironomid larvae, which are important as periphyton harvesters, persisted in the zone where algae were accumulating. In another study, depletion of invertebrates in warmed water was recorded.13

The effects of thermal discharges on benthic communities are reviewed by Stewart. 47 The number and distribution of bottom organisms usually decrease as water temperatures increase, with a tolerance limit close to $90^{\circ} \mathrm{F}$ for a "balanced" population structure. Studies of particular species of macroinvertebrates have shown that lethal temperatures vary considerably with the type of organism. In some cases, a particular species may be stenothermal at one developmental stage and eurythermal at another. Thus, a large number of species are able to live at temperatures higher than those at which they can reproduce. In a study of the York River in Virginia, Warinner and Brehmer ${ }^{48}$ found that the community composition and abundance of marine benthic invertebrates in the river are affected by thermal discharge over a distance of 1,000 to $1,300 \mathrm{ft}$ from the discharge outfall... They found clear evidence that biological stress occurs during the months of normally high river temperatures.

At power plants where benthic communities are destroyed in summer, the reverse is often the case in winter. ${ }^{47}$ Massengill 49 reports not only colonization, but also a 10 to $40 \%$ increase in standing crop in the discharge canal at the Connecticut Yankee Atomic Power Plant compared with the standing crops at stations in the Connecticut River.

Results of thermal-tolerance studies conducted on many species of aquatic organisms have been published. In many cases, these data should be regarded as optimistic estimates of upper lethal limits of the populations as a whole because, as McCauley ${ }^{50}$ stresses; lethal temperatures quoted in the literature usually have been determined for individuals of the more-hardy stages of postembryonic development. 
In the prediction of responses to increased temperature, an important fact is that a temperature not adequate to kill the organisms may, however, produce profound effects on a population. For instance, brook trout were found to be comparatively slow in catching minnows at $63^{\circ} \mathrm{F}$ and virtually incapable of catching them at $69.8^{\circ}$; this slowdown resulted in the trout essentially starving to death. 13 Many other types of sublethal effects on populations are known to occur.

Rates of metabolism and activities of organisms increase with increasing temperatures over most of the tolerated temperature range and then often decrease suddenly near the upper lethal temperature. Such rates vary with different species, processes, and levels or ranges of temperature and also may be modified by salinity and oxygen factors. Often, the effect of elevated temperatures on a biological system is considered to be an increase in the rate of biochemical reactions within the system by 100 to $600 \%$ for each $18 \mathrm{~F}^{\circ}$ increase, 51 although this rate does not necessarily hold for extreme temperatures. Application of this concept shows that even a slight temperature increase may have far-reaching effects because a number of metabolic functions will be accelerated even though the organism may not be killed outright. Fortunately, Coutant points out, 13 the actual metabolic increases on exposure to elevated temperatures are often less than would be anticipated from strictly thermodynamic considerations where, typically, metabolic rate would vary directly with temperature. If the oxidative processes of an organism are independent of temperature (thermally insensitive), then the rate of oxygen utilization would be relatively constant over a wide temperature range. Studies involving many species of invertebrates indicate that over certain parts of a temperature range in which they can be held for prolonged periods, animals tend to be metabolically independent. This kind of response is intermediate between the two extremes. In general, this thermal range of metabolic insensitivity coincides with the temperature regime of the animal's habitat. For such species, slight changes in their thermal environment have little effect as long as such changes remain within the zone of metabolic insensitivity. However, greater changes could have a pronounced effect.

In many species, the temperature requirements for reproduction are confined to ranges narrower than those for other physiological functions. ${ }^{3,51}$. Most aquatic animals breed in a very restricted temperature range. Photoperiod effects and rising temperatures in the spring induce development of the gonads, and actual spawning takes place when a certain temperature is reached, which varies for different species. In some species, the whole process may be reversed. 24 
Often, a temperature stimulus of some kind is required to induce sexual activity in aquatic animals. Frequently, this threshold is critical and may occur with a temperature rise 40 of only 1 or $2 \mathrm{C}^{\circ}$. Brandhorst ${ }^{52}$ believes that spawning activity in herring is induced by the suddenness rather than the magnitude of the temperature change. Generally, low temperatures during prespawning periods delay spawning, and higher temperatures hasten it. 40,43

Most fish have a preferred temperature range. 53 In the temperate zone, this range is generally higher than ambient water temperatures during the cooler months; therefore, fish are attracted to thermal discharges at these times. As ambient temperatures decrease in autumn, warm-water fish are believed to follow their preferred temperatures toward the discharge rather than toward their usual wintering areas. In Long Island Sound, blue fish school in the thermal plume of the Northport plant rather than follow their usual migration to deeper oceanic waters offshore. 54 Menhaden were similarly detained in their seasonal southward migration by the Oyster Creek plant on Barnegat Bay, New Jersey. As ambient temperatures drop further, as storms dissipate the thermal plume more rapidly, or as the power plant temporarily ceases to operate, the thermal drop to ambient levels may not be tolerable, and large numbers of. fish may be killed. 55,56 . Mass mortalities of animals caused by a rapid drop in winter temperature or during severe winters are well documented. $42,57-63$

Fish attracted to discharge canals and in residence there for several months may be. induced by higher temperatures to spawn early.13 Premature spawning can have many repercussions in the receiving water, which range from loss of progeny due to lack of proper food to species changes brought about by the overly dominant large warmwater fry. The problem is not unique to discharge canals but occurs in cooling ponds and in mixed water bodies wherever the water temperature is elevated. 13

Few of the theoretically predicted changes in reproductive schedules have been studied at power plants, and observations are generally limited to evidence that premature spawning can and does occur. For instance, white suckers (Catostomus commersoni) spawned prematurely in the discharge canal of the Martin's Creek Power Plant on the Delaware River. ${ }^{64}$ Spawning activities were observed earlier there than elsewhere (although specific times were not given). Young of the year were active in the spring in the canal and apparently left the warmer water as the temperature rose in summer. Very small fry of several other species (rearing determined them to be principally minnow species) were found in the canal prior to normal spawning times. They probably were spawned in the canal instead of having passed through the condensers. 13 
The attraction of fish to warm areas associated with thermal discharges may cause additional problems. For instance, fish attracted to warm discharge canals of power plants, and forced by their own temperature-selection behavior to remain there, subject themselves to speeded metabolic rates compared with their seasonal norm in other parts of their environment.

At the Connecticut Yankee Atomic Power Company's plant on the Connecticut River, Merriman and co-workers ${ }^{65}$ identified "skinny fish" in the winter accumulations of brown bullheads (Ictalurus nebulosus) and white catfish (Ictalums catus) in the discharge canal. The weight-to-length ratio, or "cond1tion factor," exhibited significant declines throughout the winter months. Fish tagged early in the winter of 1968-1969 and recaptured four months later had lost, on the averagc, $20 \%$ of their weight; some $108 \mathrm{t} 60 \%$. Comparisons of tagged and untagged fish in weekly collections indicated that this significant weight loss was not the result of the tagging but was indicative of the resident canal population as a whole. Populations in the cooler river water outside the canal also showed some condition loss, but at a much slower rate. The poorer condition was also identifiable in these two species of fish caught in the canal in the summer. Channel catfish (Ictalums pronctatus), on the other hand, showed no such decline in condition at any season.

Significance of the weight losses for ultimate survival of the populations in the Connecticut River has yet to be establ1shed, bur the persistence of the effect beyond the winter was demonstrated through tagging and recovery studies. 13 Early fall returns from fish tagged in the canal the previous winter revealed that the fish had not made up their past-winter's weight loss over the summer.

As a corollary to feeding rate and quantity of food consumed, temperature is an important factor in the evaluation of the effects of heated effluents on the growth of fish but has been studied primarily with freshwater fishes and in the laboratory. The general relation between growth rate of $f i s h$ and temperature is discussed by several authors. 40,66 Usually, reduction in growth rate can be expected with increase in temperature above that which is optimum for the species, especially if the availability of food does not increase. This situation is the result of reduced food-conversion efficiency, which in some cases may be intensified by behavioral changes such as reduced effectiveness as a predator or reduced appetite.

Certain thermal effects are particularly questioned by those concerned with potential environmental damages from power plants. Some of these are discussed below. 
Thermal Shock. Abrupt thermal rises will be experienced by small organisms (phytoplankton, zooplankton, fish eggs and larvae, and small fish) that pass through the condenser cooling system or through the discharge zone. Available literature summaries clearly show that the detrimental effects of such thermal experiences are due to both the exposure temperature and its duration. ${ }^{13}$ Basic data on time-temperature relationships of important aquatic species can be used to predict whether entrained organisms will be able to survive the particular time-temperature pattern of a particular power plant cooling system. 14 Alternatively, such predictions can be used to design cooling systems that allow passage without significant thermal damage.

Thermal Blockage. Migrating fishes may encounter the mixing zone of the discharge in their:movements and may be attracted or repelled by the thermal gradients, depending on the particular temperature patterns and on the thermal preferences and avoidance levels of the fish species.13 In principle, this could constitute a potential thermal blockage of these movements. Blockage of salmon migrations by warm tributaries has been reported. 67 Examination of preferred and upper avoidance temperatures for the local species and the water volume with temperatures above avoidance levels would indicate whether this should be a significant problem.

Chronic High Temperatures. Many resident fishes and bottom organisms will experience temperature elevations somewhat above ambient In the vicinity of the discharge. This elevation may be discontinous, however, for tidal cycling or wind-induced currents may periodically expose any fixed organism to alternating masses of warm and cool water. Ecological effects of such small temperature changes above ambient are extremely difficult to detect with present experience, and the results may not be detectable until several years (generations of aquatic organisms) have passed. The best prior examples of such long-term effects are changes in geographic (latitude) ranges of species along the Atlantic Coast with cyclic changes in climate temperatures over the past century. 68

Cold Kills. As noted earlier, attraction of fish to warm thermal discharges in winter can cause them to become metabolically acclimated to the higher temperatures and thus susceptible to death or severe stress when the power plant ceases to discharge heat. Mass mortalities under aberrant natural conditions and cold kills at power plants have been documented. 42,55-63 There are a number of ways that appropriate siting, design, and operation of power plants can minimize the liklihood of cold shock damages occurring. These are currently being summarized by the American Nuclear Society Standards Committee. 


\section{MECHANICAL AND PRESSURE CHANGES}

When organisms are drawn with cooling water through the screens and pumps and are subjected to pressure changes and outfall turbulence, they often sustain mechanical damage that generally results in death. Only recently have mechanical effects been studied separately from other effects at operating power stations, and most results are available only in the form of very tentative progress reports.

Ayers and associates 69 observed a small decrease (about 15\%) in the number of phytoplankton organisms during their passage through the cooling system of the Waukegan power plant on Lake Michigan. Since thermal damage does not destroy the cell bodies, some type of mechanical destruction must have been responsible. Scanty evidence suggests that from 15 to $100 \%$ of the zooplankton organisms may be killed, the loss depending largely on organism size. Losses of about $30 \%$ during passage through the condenser may be representative. Marcy 70,71 attributes about $80 \%$ of the mortality of larvae of American shad passing through the Connecticut Yankee plant to mechanical damage.

\section{IMPINGEMENT}

A major problem encountered during the operation of several power plants has been that of fish mortality caused by impingement on the tine-mesh screens used to filter out debris that could damage the circulating-water system. This problem has been documented best at the Indian Point Unit No. 1 Station on the Hudson River. The available information concerning these fish kills has been compiled by Consolidated Edison Company, 72 and an analysis of the information has been reported and summarized by the Division of Compliance, Director of Regulation, of the AEC. ${ }^{73}$ Analysis of 1mpingement at other sites is currently underway by many agencies.

The precise cause of the impingement problem is not understood completely. All the fish kills at Indian Point Unit 1 seem to have been associated with the plant's condenser-cooling-water system. Fish appear to be caught against the screens by the force of the river water drawn into the plant; once caught, they are unable to escape and eventually succumb to exhaustion, although the exact cause of death is not known. Several factors that may contribute to the problem have been examined. The wharf and related structures located over the intakes may appear to provide refuge for fish. Also, the discharge of heated river water from the plant causes the river water in the vicinity of the plant to be warmer in wintertime than the main body of river water. The most important factor is the capturing capacity of the large volume of water withdrawn from the river at high velocities. The only action that seems to reduce 
the level of mortality is reduction in the intake-water velocity. Present evidence indicates that a reduction in the velocity to 0.5 fps may greatly reduce the fish-kill (Fig. 4). The general applicability of this velocity limit for other environments and species has yet to be shown, however.

The magnitude of the kill undergoes definite seasonal variation, the highest mortality occurring in the winter months and the lowest in the summer. Apparently, this variation is due to reduced swimming ability of many fishes at the very $10 \mathrm{w}\left(34^{\circ} \mathrm{F}\right)$ winter temperatures.

These kills have included some 23 species, white perch being by far the predominant species and accounting for over $60 \%$ of winter fishkills. However, because of the large number of fish involved, substantial numbers of other species are also killed.

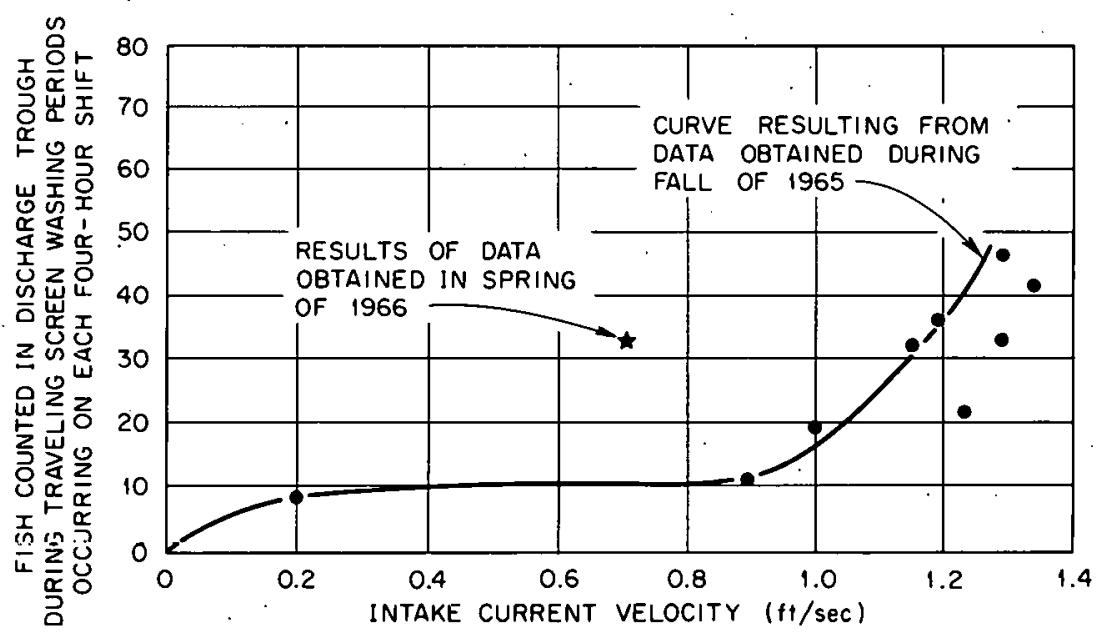

Fig. 4. Fish count per screen versus intake velocity at the Indian Point Plant on the Hudson River.

\section{ENTRAINMENT}

The importance of entrainment is related to relative quantity of organisms withdrawn from the water body, level of mortality incurred, ecological role of the entrained organisms, and reproductive strategy of the species involved. The importance of these factors will be 
species-dependent. Consequently, detailed evaluation of the effects of entrainment must be made separately for each species.

Mortality of entrained organisms is caused by mechanical damage, (including impingement), thermal shock, and (at times) chemicals discharged into the cooling water. Mortality caused by other factors associated with plant operations would, of course, be additive.

\subsection{Decomposers}

As previously indicated, bacteria are generally tolerant of exposure to changes in temperature that exceed the temperature rise of most power-plant cooling water and are also unlikely to be physically damaged as a result of entrainment. The only extensive bacterial mortality might be that caused by the chlorine added to the circulating water to control fouling in the condensers.

\subsection{Producers}

Entrainment effects on algal populations have been determined by examining the ability of algae to produce organic matter. Using this method in studies on the York River, Virginia, Warinner and Brehmer ${ }^{48}$ showed that the responses of phytoplankton to entrainment depends on the ambient stream temperature as well as on the change of temperature imposed by the condensers. At low winter temperatures $\left(32^{\circ}\right.$ to $50^{\circ} \mathrm{F}$ ), temperature rises increased production. During the summer (temperatures $59^{\circ}$ to $70^{\circ} \mathrm{F}$ ), slight additional temperature increases increased production, but larger increases (greater than $10 \mathrm{~F}^{\circ}$ ) depressed it. The greater the temperature rise in summer, the greater was the depression of the affected plankton's ability to photosynthesize.

Similar results were shown by Morgan and Stross ${ }^{74}$ for the Chalk Point Plant on the Patuxent estuary off Chesapeake Bay. In their study, temperature rises of about $14.5 \mathrm{~F}^{\circ}$ stimulated photosynthesis when natural water temperatures were $60^{\circ} \mathrm{F}$ or cooler and inhibited photosynthesis when temperatures were $68^{\circ} \mathrm{F}$ or warmer. However, at times, passage through the condensers contributed additional damage (perhaps mechanical or chemical) that nullified stimulation by temperature rise at cool temperatures and increased inhibition at warmer ambient levels. Return of phytoplankton to the region of cool temperatures of the mixed estuary at the end of the discharge canal did not allow recovery of photosynthetic ability. In relating the observed changes in productivity to the entire estuary, the authors noted that reductions in productivity might occur only if the rate of photosynthesis is not nutrient-limited. They concluded that, since Stottlemyer 75 found that nutrient limitation 
is only a sporadic occurrence, reduction in photosynthesis by another factor (the power plant) must, therefore, be responsible for any reduction in the amount of material available for passage through the food chain.

In contrast, another study showed that rates of photosynthesis were similar in power-plant intake and effluent water when algae were incubated at the prevailing temperature for each source, although some differences were significant. ${ }^{27}$ Algae in heated water had a higher rate of photosynthesis than algae incubated at ambient temperatures. The highest rates of photosynthesis occurred at temperatures between $80.6^{\circ}$ and $91.4^{\circ} \mathrm{F}$. The highest rate observed was for effluent water incubated at $86.9^{\circ} \mathrm{F}$. No consistent reduction of photosynthesis was observed in the vicinity of the discharge canal during field studies.

\subsection{Consumers}

Entrainment analysis of the coolant system should include an estimate of zooplankton mortality and the potential for a rapid recovery downstream of the power plant. Such an analysis was carried out in May 1964 at the Paradise Generating Station at Green River, Kentucky. 76 Biologists of the Tennessee Valley Authority found that the volume of zooplankton was drastically reduced during passage through the single-pass cooling system of the plant. However, organisms that bypassed the plant reproduced at an accelerated pace in water that was warmed by mixing, with a thermal discharge whose temperature was $16 \mathrm{~F}^{\circ}$ above an ambient temperature of $82^{\circ} \mathrm{F}$ (Fig. 5). Coutant ${ }^{13}$ observed that decreases in zooplankton volume could not be attributed to thermal shock effects alone. Other factors might include mechanical destruction in the condenser or piping system and predation upon carcasses and weakened individuals at or near the plant discharge. The Green River reports shed no light on these processes. 13

Heinle 77 conducted an extensive series of laboratory and field experiments to determine the effect of condenser passage on zooplankton in the brackish Patuxent estuary in the vicinity of the Chalk Point power station of Potomac Electric Power Company. Instead of examining survival alone, he observed the reproductive success, in subsequent laboratory culture, of populations that had experienced the thermal, mechanical, and chemical shocks of condenser passage. Entrained populations of some copepods were generally not as fit for reproduction as we re control groups, even when the exposure temperatures were below the laboratory-determined lethal temperatures. He attributed part of this effect to chlorination of cooling water as a normal operating routine at the plant. 
Although effects of condenser passage were identified by this research, the methodology and the lack of control over such variables as chlorination gave results of uncertain predictive utility. Within the estuary, population densities of the zooplankton organisms remained high despite high rates of natural predation and the additional losses attributable to the power plant. Certainly, the reproductive potential of the entire population exceeded the effects of condenser passage.

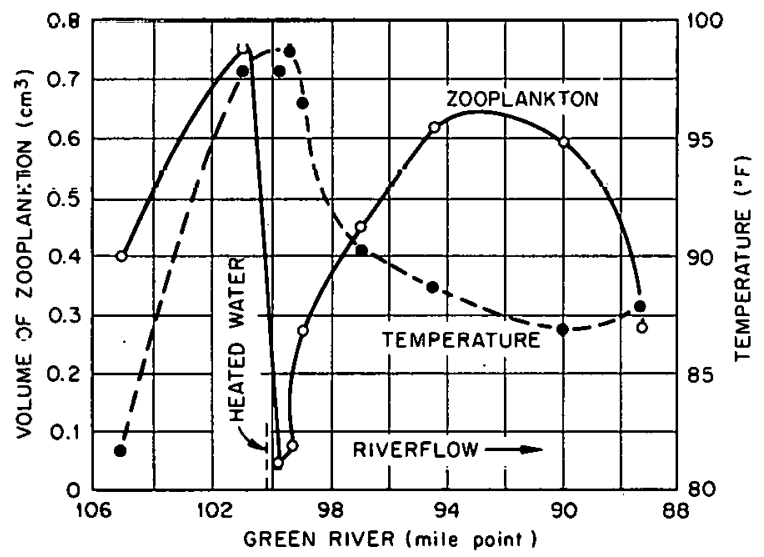

Fig. 5. Zooplankton variation with water temperature in the Green River, Ky., near the Paradise Steam Plant.

Normandeau ${ }^{78}$ clearly identified effects of condenser passage on summer zooplankton and phytoplankton at the Merrimack Generating station. Samples taken above the inlet and in the discharge canal indicated a reduction in population density of nearly all zooplankton and diatoms after they passed through the power plant. These effects were definitely related to absolute temperature, being discernible principally when the condenser-cooling-water temperatures were elevated in July to values above $100^{\circ} \mathrm{F}$. The increase in temperature alone was not the apparent causative factor; rather, mortality was evidenced when the attained temperature exceeded the tolerance limits of the species. The depressions in zooplankton population were also evident in the mixing zone in the Merrimack River downstream of the plant, although cooling water was a small percentage of the total river flow at that point. ${ }^{78}$ 
On the other hand, other studies indicate little or no damage following entrainment. Adams ${ }^{79}$ reported that the discharge canal of the Humboldt Bay Nuclear Plant on the California coast is a favorable site for natural setting of native oysters (Ostrea Zurida), cockles (Cardium corbis), little-neck clams (Protothaca stcominae), butter clams (Saxidomus giganteus), gaper clams (Tresus nuttalli), and about half a dozen other bivalves. The net flow in the canal is always outward because of domination by the cooling-water flow, and complete evacuation of the canal, as revealed by dye studies, takes place in less than $3 \mathrm{hr}$. Therefore, some of the free-swimming stages of these bivalves have to pass alive through the condenser sys tem of. the power plant in order to colonize the canal. Similar successful passage must have occurred at the Chalk Point Power Station on the Patuxent estuary to account for the high densities of invertebrates found in the discharge canal. 80,81

Profitt found that, after minnows passed through condensers of a power plant, several hundred were seen dead and dying along the banks of the effluent canal. ${ }^{82}$ In another study, preliminary. observations at the Connecticut Yankee Atomic Power Plant on the Connecticut River indicated that larval river herring ( $A$ losa spp.) were able, in July, to successfully pass through condensers in which the temperature was raised to $93^{\circ} \mathrm{F}$. All larvae were judged to be in good condition following the rapid thermal shock and collection by plankton net in the plant's discharge cana1.83 However, more-detailed studies 70 at this site showed that no larval or juvenile fish of the nine species that were entrained in the condenser cooling-water system of the plant survived. when the temperature of the canal water exceeded $86^{\circ} \mathrm{F}$.

In contrast, $\operatorname{Kerr}^{84}$ found that, generally, juvenile striped bass and chinook salmon that passed through the condenser system of a power plant had high survival. Unfortunately, the ambient water temperature was not reported. Kerr acknowledged the fact that the small striped bass would "readily go into a state of shock" during the experiments. As Coutant ${ }^{13}$ pointed out, the data from Kerr's study" have little predictive value "for application to other power plants.

In connection with Kerr's observation that the juvenile striped bass would go into a state of shock, an important fact is that the considerable mortality which may result from such shock would not be observed in laboratory studies because death is not from physiological causes. Thermal death, with a end point such as (for fish) cessation of beating of the opercula as is often used in laboratory studies, may not be the most pertinent ecological effect of acute thermal shock to organisms exposed to elevated temperatures. Heat death of cold-blooded organisms has been observed to follow a common 
pattern that includes, in sequence, loss of equilibrium, coma, and physiological death. These observations have been made with several species of fish and with amphibians and reptiles; they probably hold, in essence, for lower forms as we1l. The early stages of heat death, although not "death" in themselves, may lead to death through immobilization in the area of adverse temperature (which may prolong exposure until death results) or through stimulation of predatory activity upon the heat-injured organisms. Both results have been observed in the field and in laboratory experiments. 13

A concept of a critical exposure to heat, which causes equilibrium loss, similar to that proposed by Cowels and Bogert, ${ }^{85}$ would seem to be of paramount significançe in understanding the relations of aquatic populations to thermal shock in condenser-cooling water of a power station, as was noted by Mihursky and Kennedy. 86 Increasingly, the demise of animal populations is recognized not to depend absolutely on the physiological death limits of individuals; it involves broad ecological considerations such as breeding densities and predator-prey relationships. Equilibrium loss in the natural environment is a critical occurrence for the survival of an organism because it greatly increases the organism's susceptibility to predation.

The effect of equilibrium loss in providing stimulatory cues to predators may be a particularly important feature in fish and in other animals shocked by condenser cooling water. Mossman ${ }^{4 /}$ cites several points of evidence that suggest release of predator attack by any behavior associated with weakness. Coutant ${ }^{13}$ has specifically studied the effects of acute thermal shock and found that the vulnerability of thermally shocked juvenile salmonids to predation by larger fish increases. When both shocked and control fish were offered simultaneously under laboratory conditions, the shocked fish were found to be selectively preyed upon by larger fish. Relative vulnerability of shocked fish to predation increased with duration of sublethal exposure to lethal temperatures. Effects were also shown well below doses that cause equilibrium losses.

Confirmation of the potential importance of predation on shocked organisms in the field situations of thermal discharges can be found in the many references to predators being attracted to points of thermal discharge. ${ }^{13}$ Although preference for a particular temperature range may be the predominant attractant for some organisms, it hardly would apply to concentrations of fish-eating gulls. ${ }^{88}$ Neil189 reported intensive feeding by fish on entrained zooplankton in the outfall area of a power plant on Lake Monona, Wisconsin. Young-of-the-year bluegills congregated at the periphery of the discharge plume and fed on zooplankton. Several large longnose gar, their stomachs distended by an abundance of zooplankton, were 
taken in and near the discharge. Bigmouth buffalo, yellow bass, bluegill, black crappie, and brook silversides caught near the outfalls were suspected of feeding heavily on zooplankton, although confirming data were not collected. Abundant zooplankton were entrained by this plant in cooling water taken from $100 \mathrm{~m}$ offshore and $5.2 \mathrm{~m}$ below the water surface. The temperature rise of $18 \mathrm{~F}^{\circ}$ may have killed the zooplankton or debilitated them sufficiently that predation upon them was easier in the discharge area than in the unheated water of the lake.

Obviously, absolute statements concerning the mortality of organisms drawn through any given plant cannot be made, but the possibility is high that some fraction of the organisms entrained will be killed or damaged by entrainment.

\section{CHEMICALS}

Several chemicals are used in the power plants and are released to the environment via the cooling water discharge. Among them are chlorine (used intermittently as a biocide in the auxiliary cooling system and the condenser cooling system); copper (which corrodes continuously from copper-nickel alloy condenser tubing); sodium hydroxide and sulfuric acid, which are mutually neutralizing and yield sodium sulfate (when released intermittently from drains of acid and caustic pumps); calcium and magnesium (released intermittently from the resin beds), and some phosphates. Toxicity data on these and other power plant chemicals have been summarized by Becker and Thatcher. 90

\subsection{Chlorine}

Chlorine is used in many generating facilities to rid the coolingwater piping of bacteria, fungi, and algae. Generally, the treatments with chlorine are periodic "slugs" of high concentration (perhaps once a day, depending on the power station). The treatments affect natural populations as well as the coatings of biological materials on the condenser tubes.

The toxicity of chlorine residuals in natural waters and in laboatory tests has been documented. ${ }^{91}$ The available literature indicates that toxicity is dependent upon both concentration of chlorine residual.s and on duration of exposure. Roth timedependent acute exposures and chronic damaging levels can be identified on summary figures (Fig. 6). 


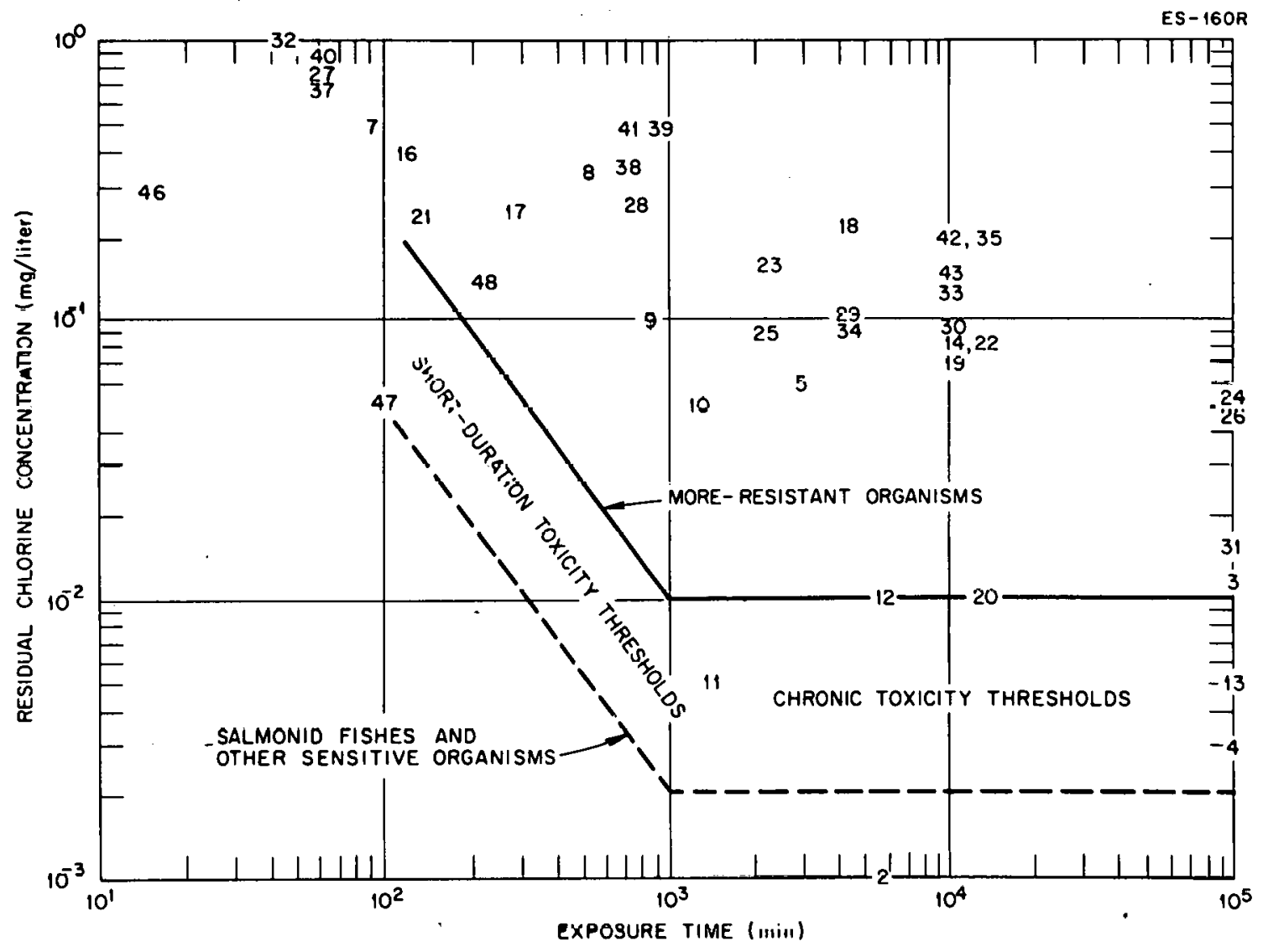

Figure 6. Summary of Residual Chlorine Toxicity Data

Numbers refer to toxicity end points for various species of organisms.

The toxicity thresholds have been estimated which bound the trend in published data. 
Key to Fig. 6. Exposures of aquatic organisms to total residual chlorine

\begin{tabular}{|c|c|c|c|}
\hline Species & $\begin{array}{l}\text { Point } \\
\text { No. }\end{array}$ & Effect end point $t^{a}$ & Reference \\
\hline Protozoa & 1 & Lethal & Hale, 1930 \\
\hline Cladoceran & 2 & Le thal (4 days) & Biesinger, 1971 \\
\hline \multirow[t]{2}{*}{ Scud } & 3 & Safe concentration & Arthur, 1971 \\
\hline & 4 & Safe concentration. & Arthur and Eaton, 1972 \\
\hline \multirow[t]{2}{*}{ Trout fry } & 5 & Lethal ( 2 days) & Coventry et al., 1935 \\
\hline & 6 & Lethal (instantly) & Coventry et al., 1935 \\
\hline \multirow[t]{9}{*}{ Brook trout } & 7 & $\begin{array}{l}\text { Median mortality } \\
(90 \mathrm{~min})\end{array}$ & Pyle, 1960 \\
\hline & 8 & $\begin{array}{l}\text { Mean survival } \\
\text { time } 8.7 \mathrm{hr}\end{array}$ & Dandy, 1967 \\
\hline & 9. & $\begin{array}{c}\text { Mean survival } \\
\text { time } 14.1 \mathrm{hr}\end{array}$ & Dandy, 1967 \\
\hline & 10 & $\begin{array}{l}\text { Mean survival } \\
\text { time } 20.9 \mathrm{hr}\end{array}$ & Dandy, 1967 \\
\hline & 11 . & $\begin{array}{l}\text { Mean survival } \\
\text { time } 24 \mathrm{hr}\end{array}$ & Dandy, 1967 \\
\hline & 12 & $\begin{array}{l}67 \% \text { lethality } \\
\text { (4 days) }\end{array}$ & Dandy, 1967 \\
\hline & 13 & Depressed activity & Dandy, 1967 \\
\hline & 14 & 7-day TLSO & Arthur, 1971 \\
\hline & 44 & Not found in streams & Tsai, 1971 \\
\hline Brown trout & 45 & Not found in streams & Tsaj, 1971 \\
\hline $\begin{array}{l}\text { Fingerling } \\
\text { rainbow trout }\end{array}$ & 17 & Lethal $(4$ to $5 \mathrm{hr}$ ) & Taylor and James, 1928. \\
\hline \multirow[t]{5}{*}{ Rainbow trout } & 15 & $\begin{array}{l}\text { Slight avoidance } \\
(10 \mathrm{~min})\end{array}$ & Sprague and Drury, 1969 \\
\hline & 16 & Lethal ( $2 \mathrm{hr}$ ) & Taylor and James 1928 \\
\hline & 18 & 96-hr TL50 & Basch, 1971 \\
\hline & 19 & 7-day TLSO & Merkens, 1958 \\
\hline & 20 & Lethal ( 12 days) & Sprague and Drury, 1969 \\
\hline Chinook salmon & 21 & First death $2.2 \mathrm{hr}$ & Holland et al., 1960 \\
\hline \multirow[t]{3}{*}{ Coho salmon } & 22 & 7-day TLSO & Arthur, 1971 \\
\hline & 23 & $100 \%$ kill ( $1-2$ days) & Holland et al., 1960 \\
\hline & 24 & Maximum nonlethal & Holland et al., 1960 \\
\hline \multirow[t]{2}{*}{ Pink salmon } & 25 & $100 \%$ kill ( $1-2$ days $)$ & Holland et al., 1960 \\
\hline & 26 & Maximum nonlethal & Holland et al., 1960 \\
\hline \multirow[t]{5}{*}{ Fathead minnow } & 27 & TLSO (1 hr) & Arthur, 1972 \\
\hline & 28 & TLSO (12 hr) & Arthur, 1972 \\
\hline & 29 & 96-hr TL50 & Zillich, 1969 \\
\hline & 30 & 7-day TLSO & Arthur, 1971 \\
\hline & 31 & Safe concentration & Arthur and Eaton, 1972 \\
\hline \multirow[t]{2}{*}{ White sucker } & 32 & Lêthàl ( $30-6 u$ minh) & Fóbès, 1971 \\
\hline & 33 & 7-day TLSO & Arthur, 1971 \\
\hline Black bullhead & 34 & 96-hr TLSO & Arthur, 1971 \\
\hline \multirow[t]{3}{*}{ Large mouth bass } & 35 & 7-day TL50 & Arthur, 1971 \\
\hline & 37 & TL50 (1 hr) & Arthur, 1972 \\
\hline & 38 & TLS0 (12 hr) & Arthur, 1972 \\
\hline \multirow[t]{2}{*}{ Smallmouth bass } & 36 & Not found in streams & Tsai, 1971 \\
\hline & 39 & $\begin{array}{l}\text { Median mortality } \\
\quad(15 \mathrm{hr})\end{array}$ & Pyle, 1960 \\
\hline \multirow[t]{3}{*}{ Yellow perch } & $4 n$ & $\mathrm{TI} .50(1 \mathrm{hr})$ & Arthur, 1972 \\
\hline & 41 & TL50 (12 hr) & Arthur, 1972 \\
\hline & 42 & 7-day TLSO & Arthur, 1971 \\
\hline Walleye & 43 & 7. day TLSO & Arthur, 1971 \\
\hline Miscellaneous fish & 46 & Initial kill $15 \mathrm{~min}$ & Truchan, 1971 \\
\hline Rainbow trout & 47 & $\begin{array}{l}100 \% \text { lethal } \\
\text { in plant effluent }\end{array}$ & $\begin{array}{l}\text { Michigan Water Resources } \\
\text { Commission, } 1971\end{array}$ \\
\hline Daphnia magna & 48 & 0 recovery & $\begin{array}{l}\text { National Water Quality } \\
\text { Lab, } 1971\end{array}$ \\
\hline
\end{tabular}

\footnotetext{
${ }^{a}$ TL50: median tolerance limit.
} 
References for Fig. 6

Arthur, John W., and John G. Eaton. 1972. Toxicity of chloramines to the amphipod, Gemmonus pseudolimnaeus Bousfield, and the fathead minnow, Pimephales promelas Rafinesque. J. Fisheries Res. Board Can.

Arthur, J. W. 1971. Progress reports. National Water Quality Laboratory, Duluth, Minn. Arthur, J. W. 1972. Progress reports. National Water Quality Laboratory, Duluth, Minn.

Basch, Robert E. 1971. In-situ investigations of the toxicity of chlorinated municipal wastewater treatment plant effluents to tainbow trout (Salmo gairdneri) and fathead minnows (Pimephales promelas). Bureau of Water Management, Michigan Department of Natural Resources, Lansing, Mich. 48926.50 pp.

Biesinger, K. E. 1971. Mrocessed report. National Water Quality Laboratory, Duluth, Minn.

Brungs. W. A. 1972. Literature review of the effects of residual chlorine on aquatic life. Environmental Protection Agoney, National Water Quality Laboratory, Duluth, Minn.

Coventry, F. L., V. E. Shelford, and L. F. Miller. 1935. The conditioning of a chloramine treated water supply for biological purposes. Ecology 16: 60-66.

Dendy, J. W. T. 1967. The effects of ehemical characteristics of the environment on the activity of an aquatic organism. Thesis. University of Toronto, Oni. Dissertation abstracts 29. B. 3132 (1969), Water Pollution Abs. (Brit.) 421708 (1969).

Fobes, Ronald L. 1971. Chlorine toxicity and its effect on gill tissue respiration of the white sucker, Costostomus commersoni (Lacepede). MS thesis. Department of Fisheries and Wildlife, Michigan State University, East Lansing. Mich.

Hale, F. E. 1930. Control of microscopic organisms in public water supplies with particular reference to New York City. New Engl. Water Works Assoc. 44: 361-385.

Holland, G. A., J. E. Lasater, E. D. Neumann, and W. E. Eldridge. 1960. Toxic effects of organic and inorganic pollutants on young salmon and trout. State of Washington, Department of Fisheries, Research Bulletin No. S, September, 1960. Pp. 198-214.

Merkens, J. C. 1958. Studies on the toxicity of chlorine and chloramines to the rainbow trout. Water and Waste Treat. 3. 7: 150-151.

Michigan Water Resources Commission, 1971. A survey of chlorine concentrations in the Weadock Power Plant discharge canal. Processed report. 6 pp.

National Water Quality Laboratory. 1971. Processed report. Duluth, Minn.

Pyle, E. A. 1960. Neutralizing chlorine in city water for use in fish-distribution tanks. Prog. Fish-Cult. 22: 30-33.

Sprague, J. B., and D. E. Drury. 1969. Avoidance reactions of salmonid fish to representative pollutants. Advances in Water Pollution Research. Proceedings of the 4th International Conference. Pp. 169-179.

Taylor, R. S., and M. C. James. 1928. Treatment for removal of chlorine from city water for use in aquaria. U.S. Bur. Fish. Doc. 1045. Rept. U.S. Comm. Fish. App. 7: 322-327.

Truchan, J. G. 1971. As reported by Brungs (1972).

Tsai, C. 1971. Water quality and fish life below sewage outfalls. Progress Report. National Resources Institute, University of Maryland, College Park, Md.

Zillich. J. A. 19692. The toxicity of the Wyoming Wastewater Treatment Plant emuent to the fathead minnow and the white sucker, July 28-August 1, 1969. Michigan Water Resources Commission, Michigan Department of Natural Resources. 7 pp.

Zillich, J. A. 1969b. The toxic effects of the Grandville Wastewater Treatment Plant effluent to the fathead minnow, Pimephnles promelas, November 17-21. 1969. Michigan Water Resources Commission, Michigan Department of Natural Resources. 9 pp.

Zillich. J. A. 1969c. The toxicity of the Wyoming Wastewater Treatment Plant effuent to the fathead minnow, December 8-12, 1969. Michigan Water Resources Commission, Michigan Department of Natural Resources. 12 pp. 


\subsection{Copper}

Oyster meats produced near the outfall of Chalk Point Plant in the Patuxent River accumulated enough copper to make them unfit for human consumption and to disqualify the area for the production of marketable oysters. 92 Generally, copper emissions from power plants are on the order of several parts per billion. These levels are lower than the natural concentrations in most aquatic environments. Thus, toxicity per se is not expected to be a problem in most locations.

\section{DISSOLVED OXYGEN}

The following analysis of the significance of dissolved oxygen is derived from a recent review by Coutant. 13 Since warm water holds less oxygen in solution than does cool water, increasing coolantwater temperatures by 18.4 to $21 \mathrm{~F}^{\circ}$, as predicted for the Ginna facility during condenser passage, theoretically will result in some loss of oxygen, which may subsequently influence aquatic organisms. For example, the concentration of oxygen in water in equilibrium with air at $82.4^{\circ} \mathrm{F}$ is $7.9 \mathrm{ppm}$, whereas at $111.2^{\circ} \mathrm{F}$ the saturation concentration is $6.1 \mathrm{ppm}$. Theoretically, another factor which tends to lower dissolved oxygen concentrations in the water that passes through a condenser is the partial vacuum at the discharge end of the condenser. This partial vacuum results because the discharge end of the condenser lies above the hydraulic gradient, a situation common to all steam plants. Often, vacuum pumps are installed in the cooling circuit to remove any accumulated air.

These theoret1cal considerations have been examined in a number of studies at operating power stations throughout the world. Alabaster and Downing, 38 after examining the literature and conducting their own studies in Britain, acknowledge that the oxygen content of water used for direct cooling may change slightly in its passage through electrical generating stations. This change appeared to be partly due to the turbulent flow in the effluent outfall causing water unsaturated with oxygen to pick up this gas, whereas supersaturated water lost it.

Analyses for dissolved oxygen in samples taken by Alabaster and Downing ${ }^{38}$. showed that most unheated water was not saturated, that either a slight rise or little change in oxygen concentration occurred in the heated water discharged from the condensers, and that, as a result, the effluent was supersaturated with respect to oxygen (and other gases). These authors made the further (very pertinent) observation that the changes were generally small compared with those that occur in most natural waters through plant photosynthesis and respiration and through the oxidation of organic effluents. 
Adams reports similar analyses at California power stations. ${ }^{79}$ Measurements of dissolved oxygen at intake and outfall points showed that dissolved-oxygen concentrations were not decreased in water that had passed through the cooling-water system. Rather, the water merely became supersaturated with oxygen. As the temperature of the effluent decreased in the mixing zone, saturation values decreased correspondingly, with little loss of dissolved oxygen.

Dissolved-oxygen surveys performed in late summer at the Northport Plant on Long Island Sound showed a mean decrease of $12.6 \%$ in dissolved-oxygen levels from intake to discharge. 54

Other studies indicate that once-through cooling towers may significantly increase the concentration of dissolved oxygen in the effluent when intake water is unsaturated. Thus, in water bodies whose oxygen concentration falls considerably below saturation levels in late summer and early autumn, cooling towers may provide some benefit as a result of the increased aeration. ${ }^{93}$

Once the cooling water has entered the main body of water, rates of oxygen demand by organic materials (both living and decomposing) will be increased because of the higher temperature. In waters that are heavily loaded with decomposing organic matter, this additional demand can exceed the rate of reoxygenation through the water surface (from the air), and dissolved oxygen levels could fall below those normally expected. ${ }^{34}$

\section{TNDIICED CTRCII.ATTION}

A little-recognized source of ecological change is the induction of new current patterns by the water flows of a once-through cooling system. Many patterns of distribution of organisms are intimately related to density (thermal) stratification, currents, concentration gradients, and the like, as any textbook of freshwater or marine ecology describes. The withdrawal and subsequent release (often elsewhere) of quantities of water that approximate $1 / 2$ to 1 million gpm by power stations will unquestionably alter some of the existing patterns. These alterations can be detrimental or beneficial, depending partly on the degree of thought that goes into their planning. Circulation patterns at the intakes may actually attract organisms into an area where they become susceptible to impingement or entrainment. At discharges, induced circulation patterns may simulate tributary streams and stimulate migration, spawning, or other functions associated with tributaries. Most of the speculated influences have not been documented, largely because of lack of adequate study. 


\section{RADIATION EFFECTS}

Although a voluminous amount of literature relates to the effects of radiation on organisms, very few studies have been conducted on the effects of chronic low-level radiation on natural aquatic populations. The more-recent and pertinent studies are reviewed by Auerbach and associates ${ }^{95}$ and by Templeton and co-workers. ${ }^{96}$ In general, the results of the studies summarized in these two reviews support the prediction that radiation effects would be difficult to detect at the dose levels normally encountered around power reactors :

"In assessing the effect of low doses of ionizing radiation, sophisticated means of detection must be used and sensitive biological endpoints are necessary as criteria for ascertaining radiation damage. In experimental practice when dose rates are lowered to 1 rad per day or less, the number of factors affecting the organism are sufficient to mask any effects that might be present. Such commonly used endpoints as survivorship, fecundity, growth, development, and susceptibility to infection have not as yet been shown to be umequivocally affected by such low dose rates. Evaluating the impact of doses of less than 1 rad per day on organisms and populations under field conditions is a challenge of considerable magnitude." 95

Aquatic organisms are exposed to both internal and external radiation. The dose from external radiation, termed submersion dose, is due to the radiation from radionuclides in the organisms' surroundings. For planktonic or pelagic organisms, this part of the total dose results from radionuclides dissolved in the water. For benthic and epibenthic organisms, part of the external dose comes from the radionuclides dissolved in the water and another part comes from radionuclides adsorbed onto or concentrated in their substrate. The radiation dose that results from dissolved radionuclides can be calculated if the concentrations of the various radionuclides in the water are known.

However, the external dose that results from radionuclides which are in the substrate of the organism is much more difficult to determine. This difficulty arises from the various behavioral characteristics of the organisms involved, which modify the magnitude of the dose from radiation originating in the substrate. In addition, the level of contamination of the substrate by a radionuclide may vary with physical parameters within the environment. For example, during periods when freshwater is predominant at Indian Point on the Hudson River, manganese-54 adsorbs onto the substrate 
but is released during periods when salt water moves into the area. ${ }^{7}$ As a result of these complications, the external dose from radionuclides concentrated in the substrate is difficult to estimate from the projected releases.

Aquatic organisms are exposed to radiation from radionuclides within their tissues, as well as to that from external sources. Doses that result from internal exposure are generally much greater than doses from external sources, except perhaps for benthic or epibenthic organisms that live in association with substrates in which radionuclides have been concentrated. Organisms accumulate radionuclides either directly from the water through epithelial tissue or indirectly by assimilation of their food. Transient releases of radionuclides into the environment are followed by transient peaks of radioactivity along the food-chain pathways. ${ }^{95}$

Knowledge of these pathways and of the rates of assimilation and turnover of radionuclides is essential for prediction of timedependent concentrations in the biota. However, chronic releases will result in steady-state concentrations in the biota, and, in these instances, concentration factors can be used to approximate the eventual equilibrium levels of radioactivity. ${ }^{3}$ Consequently, concentration factors can be used to estimate the internal doses the various organisms will receive if continually exposed to radionuclides released by power-plant operations.

\section{COMBINED EFFECTS}

\subsection{Direct effects}

An important aspect of the response of a population to abnormal mortality is associated with the manner in which the density of the population is controlled. The degree of crowding (density) and the pattern of dispersion of individuals (whether random, uniform, or clumped together in a limited area) are especially important in determining the degree of interaction among individuals of the same and of other species. Some populations tend to be selflimiting in that the rate of growth decreases as the density increases. Such populations tend to level off in density before saturation, thus ensuring that adequate resources are maintained. other populations are not self-limiting but tend to grow in geometric sequence unless checked by forces outside the population. Such populations are generally limited by limitations in habitat resources or by predation.

Generation time is another important factor in determining the response of populations to mortality. Species with very short generation times (hours or days), whose populations are regulated 
by density-dependent factors such as resource limitations, are able to maintain population levels in spite of increased mortality. Population maintenance in species with longer generation times (months or years) requires increased reproductive capability in the survivors in order to maintain the population level.

On the other hand, a species whose population is regulated by factors other than its own density, e.g., predation or competition with other species, cannot compensate for changes in survivorship of the other individuals in the population. Consequently, a sustained removal of a significant portion of such species ultimately eliminates the population in the area provided, of course, that no additional source of reproductive stock moves into the area from elsewhere.

The possible effects of increasing mortality to a population were examined by Jensen ${ }^{98}$ in conjunction with a detailed study of a population of brook trout. He used a mathematical model to estimate yield, which was fitted to the extensive data on a trout population. His results showed that a $5 \%$ increase in mortality of young-of-theyear decreased the yield of the trout fishery. In addition, an increase of mortality to $50 \%$ of young-of-the-year caused the population to become extinct, although the effect did not become apparent for several years because of normal variations in reproduction and yield.

\subsection{Indirect effects}

Less-obvious effects might accompany chronic exposure to increases in temperature (or radiation and chemical stresses from plant releases). These effects could alter food conversion, growth rate, or reproductive potential and might alter the interspecific relationships. For example, changes within the plankton populations have a potential for causing changes in populations of other trophic levels. The extent and importance of such changes would be correlated with the ecological function of the organisms involved and the relative densities of their populations.

The importance of this type of consideration can be seen in the following hypothetical example. Phytoplankton species $A$ is the principal food of zooplankton species $B$, which is the principal food for early larval stages of a dominant fish species. A power plant in the area begins to operate and increases the surface temperature several degrees over ambient temperature. Because of poor light-penetration in the slightly turbid water, the principal zone of phytoplankton growth is in the upper, thermally altered layer. Phytoplankton species $X$ is better fitted to grow and to reproduce in the warmer water and replaces species $A$. However, $X$ is a poorquality food for zooplankton $B$. Consequently, the population of 
B zooplankton decreases, and the food supply for the larval fish is diminished; thus, their yearly production is reduced significantly. As the numbers of these fish decline through several seasons, the reproductive capacity of the population declines, and they exert less and less influence in the area. If this species were a top carnivore, changes in its population could result in changes in the populations of other fish species as well. Changes in these populations would also have their effects.

The above hypothetical example demonstrates one manner in which indirect effects of pollutants may result in extensive changes in the biological composition of a body of water. The extent of these effects depends on several factors that must be known to make accurate predictions of the consequences of operation of any power plant.

(1) The species composition of the affected area must be known and the relationships between various species must be understood.

(2) The spatial and temporal distribution of the species in the area must be known.

(3) The relationships between each species and its physical environment must be understood.

(4) The sensitivity of the various species to alterations in their chemical and physical habitat must be known.

All this information would be needed to produce reliable predictions of the consequences of plant operations on the biota. Many reasons, including lacks of time, resources, and adequate sampling techniques, preclude the acquisition of the necessary information. At the Ginna site, the complex interactions of the biota with each other (especially under the continuing introduction of new species into Lake Ontario), the natural cycles of nutrients and temperature, and lake-current phenomena produce a large combination of possibilities. Unfortunately, even if all the relationships were known, reliable biological predictions of the indirect effects of the operation of the facility could not be developed with the present state of the art. As a result, assessment of these aspects of environmental effects of plant operation will be necessarily qualitative. However, over an extended period of time, the indirect effects may have far greater consequences on the biota than the direct effects. 


\section{SUMMARY}

General sources of potential biological damage from once-through cooling systems of steam electric power plants have been outlined and briefly described. These sources include temperature changes, mechanical and pressure changes, impingement on intake screens, chemical toxicity of biocides, changes in disolved oxygen, induced circulation, radiation, and combinations of all of these. Other sources of damage may arise at particular power plant sites. All of these need to be carefully considered and their effects predicted when making power plant environmental impact assessments. 


\section{REFERENCES}

1. 0. Kinne, Ed., "Environmental Factors," Part 1 in Marine Ecology, vol. 1, W1ley-Interscience, London, 1970.

2. F. E. J. Fry, "Effects of the Environment on Animal Activity," Univ. Toronto Stud. Biol. Ser. No. 55; also in Publ. Ont. Fish. Res. Lab. 68: pp. 1-62, 1947.

3. T. H. Bullock, "Compensation for Temperature in the Metabolism and Activity of Poikilotherms," Biol. Rev., $30(3)$ : 311-342 (1955).

4. J. R. Brett, "Sume Princlples In the Thermal Reyulremenls of Fishes," Quart. Rev. Biol., 31(2): 75-87 (1956).

5. F. E. J. Fry, "Animals in Aquatic Environments: Fishes," Chap. 44 in Händbook of Physiology, Section 4: "Adaption to the Environment," Amer. Physiol. Soc., Washington, D.C., 1964.

6. F. E. J. Fry, "Responses of Vertebrate Poik1lotherms to Temperature," pp. 375-409 in Thermobiology (A. H. Rose, ed.), Academic Press, London, 1967.

7. F. L. Parker and P. A. Krenkel, Engineering Aspects of Thermal Pollution, Vanderbilt Univ. Prees, Nashville, Tenn., 1969.

8. P. A. Krenkel and F. L. Parker, Biological Aspects of Thermal PolZution, Vanderbilt Univ. Press, Nashville, Tenn., 1969.

9. E. Naylor, "Effects of Heated Effluents Upon Marine and Estuarine Organisms," Adv. Mar. Biol. 3: 63-103 (1965).

10. J. Cairns, Jr., "We're in Hot Water," Scientist and Citizen, $10(8)$ : $187-198$ (1968).

11. J. R. Clàk, "Thermal Pollution and Aquatie Life," Bat. Amer. 220(3): 18-27 (1969). 
12. F. L. Parker and P. A. Krenkel, Thermal PolZution: Status of the Art, Dept. of Envir. and Water Res. Eng., Vanderbilt Univ. Report No. 3, 1969.

13. C. C. Coutant, "Biological Aspects of Thermal Pollution. I. Entrainment and Discharge Canal Effects," CRC Crit. Rev. Environ. Contr. 1(3): 341-381 (1970).

14. C. C. Coutant, "Blological Aspects of Thermal Pollution. II. Scientific Basis for Water Temperature Standards at Power Plants," CRC Crit. Rev. Envir. Contr. 3(1): 1-24 (1972).

15. V. S. Kennedy and J. A. Mihursky, Bibliography on the Effects of Temperature in the Aquatic Environment, Univ. of Maryland, Nat. Res. Inst. Cont. No. 326, 1967.

16. E. C. Raney, B. W. Menzel, and E. C. Weller, "Heated Effluents and Effects on Aquatic Life with Emphasis on Fishes: A. Bibliography," Ichthyological Associates Bull. No. 9, USAEC TID-3918 (1974).

17. C. C. Coutant, "Thermal Pollution - Biological Effects. A Review of the Literature of 1967," J. Water Poll. Cont. Fed. 40(6): 1047-1052 (1968).

18. C. C. Coutant, "Thermal Pollution - Biological Effects. A Review of the Literature of 1968," Battelle-Northwest, Report BNWL-SA-2376 [J. Water PolZ. Cont. Fed. 41(6): 1036-1053 (1969) ].

19. C. C. Coutant, "Thermal Pollution - Biological Effects. A Review of the Literature of 1969," Battelle-Northwest, Report BNWL-SA-3255 [J. Water PolZ. Cont. Fed. 42(6): 1025-1057 (1970)].

20. C. C. Coutant, "lhermal Pollution - Biological Effects," in A Review of The Literature of 1970 on Wastewater and Water Pollution Control, J. Water Poll. Cont. Fed. 43(6): 1292-1334 (1971).

21. C. C. Coutant and C. P. Goodyear, "Thermal Effects," in $A$ Review of the Literature of 1971 on Wastewater and Water PolZution Control, J. Water PolZ. Cont. Fed. 44(6): 1250-1294 (1972). 
22. C. C. Coutant and H. A. Pfuderer, "Thermal Effects," in $A$ Review of the Literature of 1972 on Wastewater and Water Pollution Control, J. Water Poll. Cont. Fed. 45(6): 1331-1369 and 45(12): 2577-2593 (1973).

23. C. C. Coutant and H. A. Pfuderer, "Thermal Effects," in $A$ Review of the Literature of 1973 on Wastewater and Water PolZution Control, J. Water PolZ. Cont. Fed. 46(6): 1476-1539 (1974).

24. L. P. Parrish, "Marinc, Eotuarine, and Anadromous Fishes;" pp. 52-82 in Temperature and Aquatic Life, Laboratory Investigation No. 6, Technical Advisory and Investigations Branch, Federal Water Yollution concrol Administratiul, 1967.

25. E. Naylor, "Effects of Heated Effluents on Marine and Estuarine Organisms," pp. 63-103 in Advances in Marine Biology, vol. 3, F. S. Russel1, Ed., Academic Press, New York, 1965.

26. L. A. Resi, "Bacteria," pp. 19-29 in Temperature and Aquatic Life, Laboratory Investigation No. 6, Technical Advisory and Investigations Branch, Federal Water Pollution Control Administrat1on, 1967.

27. D. H. Hamilton, D. A. Flemer, C. W. Keefe, and J. A. Mihursky, "Power Plenta: Effecte of Chlorination on Estuarine Primary Production," Science 169: 197-198 (1970).

28. R. Patrick, "Some Effects of Temperature on Freshwater Algae," pp. 161-185 in Biological Aspects of Thermal Pollution, P. A. Krenkel and F. L. Parker, Eds., Vanderbilt University Press, Nashville, Tenn., 1969.

29. J. Cairns, Jr., "Effects of Increased Temperatures on Aquatic Organisms," Ind. Wastes 1: 150-152 (1956).

30. F. J. Trembley, "Effect of Cooling Water from Steam-Electric Power Plants on Stream Biota," pp. 334-345 in Biological Problems in Water PolZution, C. A. Tarzewell, Ed., U.S. Public Health Service, Cincinnati, Ohio, Publication No. 999-WP-25, 1965. 
31. J. W. Foerster, "Discussion from the Floor: Heat and Freshwater Algae," p. 191 in Biological Aspects of Thermal Pollution, P. A. Krenkel and F. L. Parker, Eds., Vanderbilt University Press, Nashville, Tenn., 1969.

32. J. D. Buck, "Summary of Connecticut River Microbiology Study," pp. 36-39 in The Connecticut River Investigation, D. E. Merriman Ed., 10th Semiannual Progress Report to Connecticut Water Resources Commission, Apri1 1970.

33. L. O. Beer and W. O. P.1pes, The Effects of Discharge of Condenser Water into the IlZinois River, Industrial Bio-Test Labs., Inc., Northbrook, I11., 1969.

34. W. J. North, "Blological Effects of a Heated Water Discharge at Morro Bay, California," Proc. Int. Secoweed Symp. 6: 275-286 (1969).

35. G. P. Howells and S. Weaver, "Studies on Phytoplankton at Indian Point," pp. 231-261 in Hudson River Ecology, G. P. Howe11s and G. J. Lauer, Eds., New York State Department of Environmental Conservation, 1969.

36. R. L. Heffner, G. P. Howells, G. J. Lauer, and H. J. Hirshfield, "Effects of Power Plant Operation on Hudson River Estuary Micro Biota," Proc. Nat. Radioecol. Symp. 3rd, Oak RIdge, TN, 1971, 619-629.

37. F. E. J. Fry, J. S. Hart, and K. F. Walker, "Lethal Temperature Relations for a Sample of Young Speckled Trout (Salvelinus fontinalis)," Univ. Toronto Stud. Biol. Ser. 54 (1946); also in Publ. Ont. 'Fish. Res. Lab. 66: 5 (1946).

38. J. S. Alabaster and A. L. Downing, "A Field and Laboratory Investigation of the Effect of Heated Effluents on Fish," Fishery Investigations Ser. 1, Ministry of Agriculture, Fisheries and Food, U.K., 6: 1-42 (1966).

39. J. B. Sprague, "Resistance of Four Freshwater Crustaceans to Lethal High Temperature and Low Oxygen," J. Fish. Res. Bd. Con. 20: 387-4.1.5 (1.963). 
40. J. R. Brett, "Some Principles in the Thermal Requirements of Fishes," Quart. Rev. Biol. 31: 75-87 (1956).

41. J. C. Galloway, "Lethal Effects of the Cold Winter of 1939/40 on Marine Fishes at Key West, Florida," Copeia 2: 119 (1951).

42. G. Gunter and H. H. Hildebrand, "Destruction of Fishes and Other Organisms on the South Texas Coast by the Cold Wave of January 28-February 3, 1951," Ecology 32(4): 731-735 (1951).

43. 0. P. De Sylva, "Theoretical Considerations on the Effects of Heated Effluents on Marine Fish," pp. 229-293 in Biological Aspects of Thermal Polzution, F. A. Krenkel and F. L. Parker, Eds., Vanderbilt University Press, Nashville, Tenn., 1969.

44. B. J. Rothsch11d, "Production and Survival of Eggs of the American Smelt, Osmerus mordax (Mitchill) in Maine," Trans. Amer. Fish Soc. 90(1): 43-48 (1961).

45. A. B. Albrecht, "Some Observations on Factors Associated with Survival of Striped Bass Eggs and Larvae," Calif. Fish Game 50(2): 100-113 (1964).

46. C. C. Coutant, "The Effect of Heated Water Effluent Upon the Macro-Invertebrate Riffle Fauna of the Delaware River," Proc. Penn. Acad. Sci. 36: b8-71 (1962).

47. R. K. Stewart, "Aquatic Plants and Benthos," pp. 83-96 in l'emperature and Aquatic Life, Laboracory Invesigation No. 6, Technical Advisory and Investigations Branch, Federal Water Pollution Control Administration, 1967.

48. J. W. Warinner and M. L. Brehmer, "The Effects of Thermal Effluents on Marine Urganisms," Int. J. Air Water FolZut. 10(4): 277-289 (1966).

49. R. R. Massengill, "Changes in Species of Bottom Organisms Composition Relative to Connecticut Yankee Plant Operation," pp. 6-12 in The Connecticut River Investigation, D. E. Mcrriman, Ed., 9 th Semiannual Progress Report to Connecticut Water Resources Commission, October 1969. 
50. R. W. McCauley, "Thermal Relations of Geographic Races of Salvelinus," Con. J. Zoo. 36: 655-662 (1958).

51. G. Gunter, "Temperature," Chap. 8 in Treatise on Marine Ecology and Palaeoecology, J. W. Hedgepeth, Ed., Geol. Soc. Amer. Mem. 67: 159-184 (1957).

52. W. Brandhorst, "Spawning Activity of Herrings and the Growth of Their Larvae in Relation to Temperature and Salinity Conditions," p. 218 in Int. Oceconogr. Congr., M. Sears, Ed., American Association for the Advancement Science, Washington, D.C. (1959).

53. R. G. Ferguson, "The Preferred Temperature of Fish and Their Mid-Summer Distribution in Temperate Lakes and Streams," J. Fish. Res. Bd. Can. 15(4): 607-624 (1958).

54. Studies on the Effects of a Stean-Electric Generating Plant on the Marine Environment at Northport, New York, Marine Sciences Research Center, Technical Report 9, Stony Brook, N.Y., 1971.

55. "Thermal Fish Kill," Sport Fishing Institute BulZ. No. 232: 7 (1972).

56. "Thermal Pollution Fish Kill," Sport Fishing Institute Bull. No. 223: 3-4 (1971).

57. M. Brogersma-Sanders, "Mass Mortality in the Sea," Geol. Soc. Amer. Mem. 67(1): 941-1010 (1957).

58. P. M. Woodhead, "The Death of Fish and Sub-Littoral Fauna in the North Sea and the English Channel During the Winter of 1962-63," J. Anim. Ecol. 33: 169-173 (1964).

59. M, D. Dahlberg and F. G. Smith, "Mortality of Estuarine Animals Due to Cold on the Georgia Coast," Ecology 51(5): 931-933 (1970).

60. M. Storey, "The Relation Between Normal Range and Mortality of Fishes Due to Cold at Sanibel Island, Florida," Ecology 18(1): 10-26 (1937). 
61. W. Templeman, "Mass Mortalities of Marine Fishes in the Newfoundland Area Presumably Due to Low Temperature," Int. Comm. N.W. Atl. Fish., Spec. Publ. 6: 137-148 (1956).

62. W. C. Allee, "Studies In Marine Ecology: IV. The Effect of Temperature in Limiting the Geographical Range of Invertebrates of the Woods Hole Littoral," Ecology 4(4): 341-354 (1923).

63. D. J. Crisp, "The Effects of the Winter of $1962 / 63$ on the British Marine Fauna," Helgolaender Wiss. Meeresunters. 10: 313-327 (1964).

64. F. J. Trembley, Ree earch Project on Effects of Condenser Discharge Water on Aquatic Life, Progress Report 1956-59, Institute of Kesearch, Lehigh Universicy, Bethlehem, $\mathrm{Pa}$. 1960 .

65. D. Merriman et al., The Connecticut River Investigation, semiannual progress reports to lonnecticut Yankèe Atomic Power Co., Haddam, Conn., 1965 and continuing.

66. F. E. J. Fry, "The Aquatic Respiration of Fish," pp. 1-63 in The Physiology of Fishes. 1, M. E. Brown, Ed., Academic Press, New York, 1957.

67. R. L. Major and J. L. Mighell, "Influence of Rocky Reach Dam and the Temperature of the Okanagan R1ver on the Upstream Migration of Sockeye Salmon," Fishing BulZ. 66(1): 131-147 (1966).

68. C. C. Taylor, H. B. Bigelow, and H. W. Graham, "Climatic Trends and the Distribution of Marine Animals (Fishery Bulletin 115), Fishery Bulletin of the Fish and Wildife Service, Vol. 57, 1957.

69. J. C. Ayers, R. F. Anderson, N. W. O'Hara, and C. C. Kidd, Benton Harbor Power Plant Limnological Studies. Part IV. Cook Plant Preoperational Studies 1969, Special Report No. 44, Great Lakes Research Division, University of Mich1gan, Ann Arbor, 1970. 
70. B. C. Marcy, Jr., "Survival of Young Fish in the Discharge Canal of a Nuclear Power Plant," J.Fish. Res. Bd. Can. 28: 1057-1060 (1971).

71. B. C. Marcy, Jr., "Vulnerability and Survival of Young Connecticut River Fish Entrained at a Nuclear Power Plant," J. Fish. Res. Bd. Can. 30: 1195-1203 (1973).

72. Fish Protection at Indian Point, Environmental Report Supplement for Indian Point Unit No. 2, Appendix S, 1970.

73. Report of Inquiry into Allegations Concerning Operation of Indian Point 1 Plant of Consolidated Edison Company (for Period of August 1962 to June 1970), Vo1. I and II, Report Details, Division of Compliance, Director of Regulation, U.S. Atomic Energy Commission, July 1971.

74. R. P. Morgan and R. G. Stross, "Destruction of Phytoplankton In the Cooling Water Supply of a Steam Electric Plant," Chesapeake Sci. 10(3/4): 165-171 (1969).

75. J. R. Stottlemyer, Plant Nutrients and Primary Production in the Patuxent River Estuary, Thesis, University of Maryland, College Park, 1964.

76. M. A. Churchill and T. A. Wojtalik, "Effects of Heated Discharges: The TVA Experience," Nucl. News 12(9): 80-86 (1969).

77. D. R. Heinle, "Temperature and Zooplankton," Chesapeake Sci. 10(3/4): 186-209 (1969).

78. D. A. Normandeau, The Effects of Thermal Releases on the Ecology of the Mermimack River, report to Public Service Company of New Hampshire, undated.

79. J. R. Adams, "Therma1 Power, Aquatic Life and Kilowatts on the Pacific Coast," Nucl. News 12(9): 76-79 (1969).

80. R. L. Cory and J. W. Nauman, "Epifauna and Thermal Additions In the Upper Patuxent River Estuary," Chesapeake Sci. $10(3 / 4)$ : 210-217 (1969). 
81. J. W. Nauman and R. L. Cory, "Thermal Additions and Epifaunal Organisms at Chalk Point, Maryland," Chesapeake Sci. 10(3/4): 218-226 (1969).

82. M. A. Profitt, Effects of Heated Discharge upon Aquatic Resources of White River at Petersburg, Indiana, Indiana Univers1ty Water Research Center, Report No. 3, 1969.

83. B. C. Marcy, Jr., "Resident Fish Population Dynamics and Early Life History Studies of the American Shad in the Lower Connecticut River," pp. 13-32 in The Connecticut River Investigation, D. E. Merriman, Ed., 9th Semiannual Progress Report to Connecticut Water Resources Commission, October $21,1969$.

84. J. E. Kerr, Studies on Fish Presemation at the Contra Costa Steam Plant of The Pacific Gas and Electric Company, Fish. Bull. No. 92, Calif. Dept. of Fișh and Game, 1953.

85. R. B. Cowles and C. M. Bogart, "A Preliminary Study of the Thermal Requirements of Desert Reptiles," BuZZ. Amer. Mus. Natur. Ilist. 83: 265-296 (1944).

86. J. A. Mihursky and V. S. Kennedy, Water Temperature Criteria to Proteat Aquatio Lifo, American Fisheries Socioty Spocial Publication No. 4, 1967, pp. 20-32.

87. A. S. Mossman, E'xperimental Studies of Fitness as Measured by Vulnerability to Predation, Ph.D. Dissertation, University of Wisconsin, Madison, 1955.

88. E. G. Prentice, GulZ Predation in a Reactor Discharge Plzone, BNWL-1050, Battelle Northwest, Richland, Wash., 1969.

89. W. H. Ne111, Ecological Resporses of Lake Monona (Dade County, Wisconsin) Fishes to Heated Influent Water, Annual Progress Report, Wisconsin Utilities Association, September 1969.

90. C. D. Becker and T. O. Thatcher, "Toxicity of Power Plant Chemicals to Aquatic Life," U.S. Atomic' Energy Comm., WASH-1249 (1973). 
91. W. A. Brungs, "Effects of Residual Chlorine on Aquatic Life," J. Water Poll. Cont. Fed. 45(10): 2180-2193 (1973).

92. W. H. Roosenburn, "Greening and Copper Accumulation in the American Oyster, Crassostrea virginica, in the Vicinity of a Steam Electric Generating station," Chesapeake Sci. 10(3/4): 241-252, 1969.

93. C. C. Burwell, Water Pollution and Electricity Production: The Open Cycle Cooling Tower for Streom Aeration - A Preliminary Evaluation, internal document, Oak RIdge National Laboratory, July 13, 1971.

94. F. L. Parker and P. A. Krenkel, Thermal Pollution: Status of the Art, Report No. 3, Department of Environmental and Water Research Engineering, Vanderb1lt University, Nashville, Tenn., 1969.

95. S. I. Auerbach, D. J. Nelson, S. V. Kaye, D. E. Reichle, and C. C. Coutant, "Ecological Considerations in Reactor Power Plant Siting," pp. 805-820 in Environmental Aspects of Nuclear Power Stations, (STI/PUB/261), International Atomic Energy Agency, Vienna, 1970.

96. W. L. Templeton, R. E. Nakatani, and E. Held, "Radiation Effects," pp. 223-239 in Radioactivity in the Marine Environment, National Academy of Sciences, Washington, D.C., 1971.

97. J. W. Lentsch, T. J. Kreip, M. E. Wrenn, G. P. Howe1ls, and M. Eisenbud, "Stable Manganese and Mn-54 Distributions in the Physical and Biological Components of the Hudson River Estuary," in Proc. Nat. Radioecol. Symp., 3rd, Oak Ridge, TN, 1971, 752.-768.

98. A. L. Jensen, "The Effect of Increased Mortality on the Young in a Population of Brook Trout. A Theoretical Analysis," Trans. Amer. Fish. Soc. 100(3): 456-459 (1971). 


\section{THIS PAGE.}

\section{WAS INTENTIONALLY LEFT BLANK}


INTERNAL DISTRIBUTION

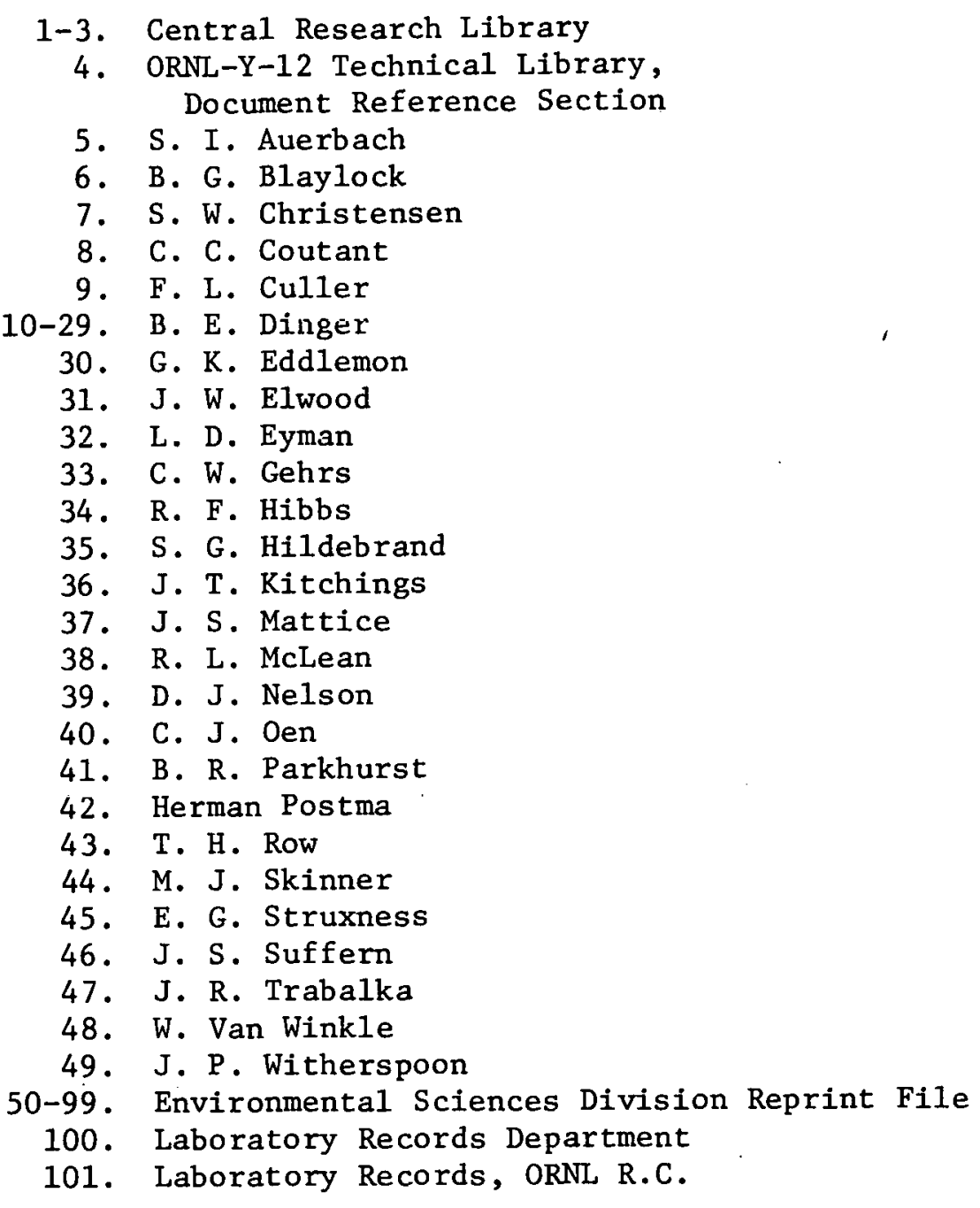

EXTERNAL DISTRIBUTION

102-103. Technical Information Center, AEC-ORO

104. Research and Technical Support Division, AEC,ORO 